\title{
Tulane
}

Tulane Economics Working Paper Series

\section{Education Expansion and Decline in Tertiary Premium in Brazil: 1995-2013}

\author{
Yang Wang \\ Department of Economics \\ Tulane University \\ ywang18@tulane.edu
}

Working Paper 1525

November 2015

\begin{abstract}
According to the Brazil Naional Household Survey 1995-2013 data, the decline in the relative wage of tertiary-educated workers coincides with an education expansion that shifted the relative supply and might also change the quality composition of the tertiary group. This paper tries to decompose the change in the tertiary premium in Brazil during the 1995-2013 period into the "price effect", which refers to the change in educational premium caused by the shifts in suppl and demand, and the "composition effect", which refers to whether there was any significant decline in the average quality of tertiary-educated workers of the recent cohorts and how the changes in cohort quality had impacted the relative wage of the tertiary group. The results demonstrate that the growth in the relative supply had a significant negative impact on the decline of tertiary premium. The results also show that the average quality of the tertiary-educated workers of the recent cohorts declined, which also accounts for a substantial proportion of the decline in the relative wage.
\end{abstract}

Keywords: earning inequality, education expansion, decline in tertiary premium, skill supply and demand, average cohort quality JEL codes: I24, I26, J24, J31, O15 


\title{
Education Expansion and Decline in Tertiary Premium in Brazil: 1995-2013
}

\author{
Yang Wang1
}

November $12^{\text {th }}, 2015$

\begin{abstract}
According to the Brazil National Household Survey 1995-2013 data, the decline in the relative wage of tertiary-educated workers coincides with an education expansion that shifted the relative supply and might also change the quality composition of the tertiary group. This paper tries to decompose the change in the tertiary premium in Brazil during the 1995-2013 period into the "price effect", which refers to the change in educational premium caused by the shifts in supply and demand, and the "composition effect", which refers to whether there was any significant decline in the average quality of tertiary-educated workers of the recent cohorts and how the changes in cohort quality had impacted the relative wage of the tertiary group. The results demonstrate that the growth in the relative supply had a significant negative impact on the decline of tertiary premium. The results also show that the average quality of the tertiary-educated workers of the recent cohorts declined, which also accounts for a substantial proportion of the decline in the relative wage.
\end{abstract}

Keywords: Earning Inequality, Education Expansion, Decline in Tertiary Premium, Skill Supply and Demand, Average Cohort Quality

JEL Codes: I24, I26, J24, J31, 015

\footnotetext{
${ }^{1}$ Email: ywang18@tulane.edu. Mailing Address: 6823 St. Charles Avenue, 206 Tilton Hall, Department of Economics, Tulane University, New Orleans, LA, 70118. The paper has benefited from valuable comments and constructive suggestions to earlier versions of the paper by Nora Lustig, Luis F. Lopez-Calva, John Edwards, Otavio Bartalotti, James Alm and participants at the wage inequality workshop at the World Bank.
} 


\section{Introduction:}

Wage inequality declined substantially in Brazil between 1995 and 2013. According to the Brazil National Household Survey ${ }^{2}$ data, the Gini coefficient of hourly wage of all full-time workers continuously declined from 0.53 in 1995 to 0.45 in 2013. Wage inequality is determined by distribution of skills in the labor force and the prices of the skills in the labor market (Katz and Autor, 1999). Decomposition analysis concludes that the changes in prices of workers' different skills were the main force in changing the wage distribution in Brazil during this period (Ferreira et al., 2015). Among all the movements in skill prices, the change in educational premium is the most conspicuous: the relative average return of each education group with respect to the incomplete primary education group (0-3 years) declined throughout 19952013 in which the most significant decline occurred among the tertiary group (12+ years). In absolute term, the average hourly wage of workers with college education and above decreased from 7.9 reals in 1995 to 6.3 reals $^{3}$ in 2013. The average hourly wage of workers with complete secondary education also decline: it was 3.1 in 1995 and 2.5 in 2013. For workers with other lower education levels, average hourly wage increased between 1995 and 2013 and the extent of increase is negatively correlated with the education level.

The wage convergence among education groups coincides with a large expansion of higher education, which has been one of the most significant changes in the labor markets of Brazil and other Latin American countries since the 1980s. In 1995,

\footnotetext{
2 Name in Portuguese is written as "Pesquisa Nacional por Amostra de Domicílios".

${ }^{3}$ All wage measures discussed in this paper are in 1995 price.
} 
among all economic active people aged $16-65$, there were $9.5 \%$ of them with tertiary education and this ratio raised up to $18.9 \%$ in 2013 . On the other hand, $47.1 \%$ of them were with primary or less education (0-3 years) in 1995, which declined to $19.9 \%$ in 2013. Given the coincidence of the decline in education premium and the education expansion, an immediate question is to what extent the change in education premium in Brazil is accounted for by the shifts in relative supply of more-skilled workers and how it is related to the decline in wage inequality.

Other than the impact of relative supply, the change in relative demand would also affect relative skill premium. According to the Heckscher-Ohlin model, globalization would increase the skill premium in countries which possess more skilled labor, and decrease the skill premium in countries with more abundant less skilled labor, which is the case of Brazil (Harrison and Hanson, 1999; Goldberg and Pavcnik, 2007). According to Autor, Katz and Kearney (2008), the evolution of college to high school premium in the US includes a decline during the 1970s, a significant increase during the 1980s, and then mild increase since the 1990s. In contrast, both Brazil and Mexico (Campos-Vazquez et al., 2014) observed declines in relative return to tertiary education in the past two decades. Thus, it is also of interest to know whether the decline in education premium happened in Brazil was caused by any decrease in relative demand of more-skilled workers, or was because the increase in supply dominated the change in relative demand.

Other than the shifts in relative supply and relative demand of more-skilled workers, the decline in relative return to tertiary education could also be caused by a decline 
in the average quality of the tertiary-educated workers of the more recent cohorts in the process of education expansion, which is called the "Degraded Tertiary Effect" (Lustig, Lopez-Calva and Ortiz-Juarez, 2013). There are two possible explanations for the deterioration of workers' average quality. First, if the ability distribution is fixed across cohorts and people with higher ability attend college, the enrollment of additional students with lower marginal ability during the expansion of tertiary education might drag down the average quality of this group. Second, even assuming the ability distribution among individuals pursuing higher education is the same across periods, if there were not enough resources built to accommodate the expansion, the education resources would be diluted when more people are sharing the same amount of resources, which might also lower the quality of college graduates.

The change in the average quality of the tertiary group is an important indicator of the efficiency of the education expansion. Taubman and Wales (1972) find the average quality of the tertiary group increased in the US during the 1990s based on a series of test score statistics. Juhn, Kim and Vella (2005) find a small decline in the average quality of the more educated cohort during the 1940-1990 period in the US, which only accounted for a small fraction of the change in the college wage premium. Canerio and Lee (2011) demonstrate a decline in the average quality of tertiary workers during 1960-2000 in the US. However, little research has been conducted in the context of less developed countries, although this question is particularly important for countries with scarcer resources. 
This paper decomposes the change in the tertiary premium in Brazil during the 1995-2013 period into the "price effect", which refers to the change in the educational premium due to the impact of shifts in relative supply and relative demand, and the "composition effect", which refers to whether there was any significant change in cohort quality and how the changes in cohort quality had impacted the relative wage of the tertiary group. The specific questions the paper explores are the following two. First, the changes in the relative return to the tertiary group in Brazil between 1995 and 2013 are examined to see how much of the change is accounted for by the shifts in the relative supply and relative demand of workers with tertiary education, following the supply-demand approach of Autor, Katz and Kearney (2008). Second, the "degraded tertiary effect" is examined following Juhn, Kim and Vella (2005). The specific hypothesis is whether the tertiary premium paid to workers from a more educated cohort decreased, controlling for everything else that also affect the tertiary premium. The educational level of each cohort is controlled by the variation in the relative size of tertiary-educated workers of each birth-year cohort. The decrease in the average quality is inferred from the decrease in the relative wage. This paper contributes to the literature as the first paper exploring the reasons behind the decline of tertiary premium in Brazil in the most recent period. Second, the identification of the impact of relative demand on skill premium contributes as an empirical testing of the Heckscher-Ohlin model in the context of Brazil. Besides, identifying whether there is any deterioration of the tertiary education provides very important policy perspectives for efficient education reform. 
When analyzing changes in the relative wage and the relative supply of the tertiary group, the reference group is those with an incomplete secondary education. The results demonstrate that the growth in the relative demand was the main cause for the mild increase in the relative return to tertiary group during the 1995-2004 period. For the decline in the tertiary premium during the 2004-2013 period, it was because the increase in the relative supply exceeded the increase in the relative demand. Thus, there is no decrease in relative demand of skilled workers in Brazil in the past two decade. Then, the change in the average quality of the tertiary group is further tested; we find the tertiary premium of the most recent cohorts decreased while controlling for the impact of expanded supply, which is measured by the proportion of workers with tertiary education in each birth-year cohort, from which we make the inference that the average quality of the tertiary group declined during this period.

The structure of the paper is as follows. Section 2 summarize relevant literature. Section 3 introduces the data and samples for analysis as well as the evolution of wage inequality, wage structure and education distribution in Brazil between 1995 and 2013. Section 4 describes the supply-demand framework employed for analysis and presents estimates of the role of supply and demand in the changing wage differential of the tertiary group. Section 5 analyzes the degraded tertiary hypothesis, and section 6 concludes the paper. 


\section{Relevant Literature}

This section summarizes two themes of researches in the literature, which are related to the research questions of this paper. One on variation in tertiary premium and the other on how educational composition and educational premium are correlated with wage inequality. However, research on identifying the causes behind variation in educational premium in the context of Brazil has rarely been done.

For the change in tertiary premium in Brazil, Green et al. (2001) studied the skill premium in Brazil between 1981 and 1999. They found an increase in return to tertiary education after 1990 and it is mainly attributed to increase in relative demand. The impact of this increase in tertiary premium on wage inequality is negligible due to the small size of the tertiary group. Blom et al. (2001) studied a similar period that is between 1982 and 1998, and found the return to tertiary education increased sharply while return to primary and secondary decline. The change in return to education is the main reason of the mild decline in wage inequality. Both Green et al. (2001) and Blom et al. (2001)'s findings suggest increase access to higher education would be beneficial in terms of reducing wage inequality. Barros et al. (2010) found wage differentials of different education levels had started to decline since 1995 and the reduction was more obvious after 2002, especially for secondary and tertiary education, which is one of the most important factors contributing to recent decline in wage income inequality. 
For the relation between education expansion and wage inequality, according to Green et al. (2001), the Gini coefficient of wage income increased from 0.55 in 1981 to 0.61 in 1989 then declined after 1990 when the trade reform took place in Brazil. Ferreira and Barros (1999) find wage inequality was basically unchanged comparing 1976 and 1996 because the impact of decline in return to higher education counterweighted the impact of education expansion of the labor force. Ferreira et al. (2007) found education expansion in the context of highly convex return was an important reason for the increase in inequality during 1980s and the decline in inequality between 1993 and 2004 was accounted by declines in returns to education, convergence between rural and urban, effective transfer programs and a decline in inequality among races. Barros et al. (2010) found that the accelerated education expansion in Brazil during 2001-2007 had accounted half of the decline in wage income inequality and the recent decline in wage income inequality was caused by a convergence in return differentials across education groups as well as a more equal distribution of education. Besides, the change in educational premium is more important than education expansion in explaining the decline.

\section{Data and Statistical Analysis:}

The data employed in this analysis come from a series of the annual Brazil National Household Survey (PNAD) covering the period between 1995 and 2013. The PNAD survey is collected by the Brazilian Institute of Geography and Statistics (IBGE), which covers the general characteristics of the population, including health, education, job characteristics, household income and housing conditions. The wage 
income in the analysis includes both cash income and values of goods and products paid from one's primary job. For the purpose of comparison across years, the nominal wages of each year are deflated to real values in 1995 prices utilizing CPI conversion factors from IBGE. The education groups defined in this paper are the following (Ferreira, Firpo and Messina, 2014; Ferreira and Barros, 1999, Blom, Holm-Nielsen and Verner, 2001): primary incomplete (0-3 years of education), primary complete (4 years of education), secondary incomplete (5-10 years of education), secondary complete (11 years of education) and tertiary incomplete and complete $(12+$ years $)$.

Two sets of samples are defined for answering the research questions: the wage samples and the supply samples. For both sets of samples, the $1^{\text {st }}$ and $99^{\text {th }}$ percentiles are trimmed for each gender-education-year group. First, the wage samples include all full-time workers aged 16-65 who reported working at least 140 hours per month, not currently a student, not working without pay nor being domestic workers; employers, employees and the self-employed are all included. The wage measure employed in this analysis is the hourly wage generated by dividing the reported monthly wage by 4.33 times the reported hours worked per week (Campos-Vazquez et al., 2014). Second, the supply samples include all individuals aged between 16 and 65 who reported working at least 1 hour during the survey month; students and those working without pay are excluded from the supply; all employers, employees, self-employed and domestic workers are included. 
After introducing the survey data and stating the sample selection criteria, the following several paragraphs describe the evolution of wage inequality, changes in wage structure and upgrade of education attainment of the labor force based on the samples.

\subsection{Changes in Wage Inequality and Wage Structure}

Brazil is a country of great diversity and high income inequality. The evolution of income inequality in Brazil has been well documented. It rose between 1960 and 1976 then declined between 1977 and 1981. According to Ferreira, Leite and Litchfield (2008), income inequality increased between 1981 and 1989 and there is a peak period during 1989-1993, then inequality declined between 1993 and 2004, which changed Brazil from the $2^{\text {nd }}$ most unequal country in the world in 1989 to the $10^{\text {th }}$ in 2004. A more recent study by Barros et al. (2010) found the Gini coefficient declined from 0.593 in 2001 to 0.552 in 2007 and the changes in wage income distribution accounted for 31 percent to 46 percent of the decline.

According to my data, the wage inequality declined continually and substantially during 1995-2013. Figure 1 presents the evolution of hourly wage inequality across years for all full-time workers, in which the Gini coefficient and 90-10 log differential significantly declined. The data exhibits a similar changing pattern when analyzing females and males separately. The decline in wage inequality is also observed in every education group except the tertiary group. As shown in figure 2, the wage inequality of the tertiary group was stable and always the highest among 
all educational groups during 1995-2013; this is different from all other education groups.

The wage structure changed significantly between 1995 and 2013, which is the main cause of the decline in wage inequality. The real average hourly wage of all full-time workers increased 26\%, comparing 2013 with 1995, which involves a decline during 1995-2004 and an increase during 2004-2013, as shown in figure 3. Figure 4 shows the evolution of the average hourly wage of each education group, as we can see, the tertiary group experienced the most significant decline. Comparing 2013 with 1995, the average absolute wage of the incomplete primary group increased $52 \%$, the complete primary group increased $13 \%$, the incomplete secondary group increased 5\%, and both the complete secondary and tertiary group declined about $20 \%$.

While analyzing the change in the tertiary premium, the relative return and relative supply of the tertiary group is measured with respect to the incomplete secondary group--those with 5-10 years of education. Figure 5 presents the relative return to tertiary with respect to incomplete secondary education across years. Figure 5 is generated based on the wage samples, and the relative premium is compositionadjusted $^{4}$. The composition-adjusted tertiary premium represents the premium for a fixed composition of workers--the average composition over 1995-2013 period according to Autor, Katz and Kearney (2008); thus, the changes in relative wage reflect only the change in wage structure but not changes in the composition of

\footnotetext{
${ }^{4}$ See data appendix about how the composition-adjusted wage measure and supply measure in efficiency units are constructed.
} 
workers' characteristics. In correspondence, the relative supply measure is in efficiency units. These are conventions for analyzing the impact of supply and demand on relative wages, see Katz and Murphy (1992), DeLong, Goldin and Katz (2003), Acemoglu and Autor (2011), Autor (2014), Goldin and Katz (2007), and Autor, Katz and Kearney (2008), etc. This allows us to filter out the possible impact of the deterioration in workers' average quality while analyzing the impact of supply and demand. As we see from the graph, the tertiary premium increased slightly between 1995 and 2004 and then declined between 2004 and 2013. Correspondingly, figure 6 presents the log of the relative supply of the tertiary group with respect to the incomplete secondary group. Figure 6 is generated based on the supply samples, and supply is measured in efficiency units, which are comparable to the composition-adjusted wage measure. As we see, the relative supply was stable between 1995 and 2004 and then increased sharply after 2004, which reflects the fast expansion of tertiary education. Comparing figure 5 with figure 6, the increase in the tertiary premium between 1995 and 2004 might reflect the increase in the relative demand of the tertiary workers given the stable relative supply. For the decline in the tertiary premium between 2004 and 2013, given the sharp increase in the relative supply, it might be because the change in the relative demand was not fast enough to digest the growth in the relative supply.

\subsection{Changes in Educational Attainment}

The average years of education of male workers aged 16-65 increased from 5.53 in 1995 to 8.34 in 2013. Among all economically active male workers aged 16-65 (in 
the supply samples, employers, employees, self-employed and domestic workers are included), $52 \%$ of them were with primary or less education in 1995, and $12 \%$ had attended college in 1995. In 2013, the proportion with primary or less education declined to $24 \%$, and the proportion who had attended college increased to $30 \%$. The evolutions of the education distributions of economically active females exhibited a similar pattern during the period under analysis. In addition, throughout the entire period, economically active females were always more likely to have attended college compared to economically active males in Brazil.

Additionally, there was an acceleration in education attainment among the younger cohorts. Figure 7 presents the average years of education of each birth year cohort at age 30 separately for economically active males and females aged 16-65. To generate this graph, all economically active males/females aged between 16 and 65, which covers those born between 1932 and 1994, were pooled together, and then the male/female samples were grouped into cells defined by birth year and age. The log of the average years of education in each cell is regressed on a set of birth year dummies and a quartic in age (R-squared for both male and female regressions are above 0.9 ), and then the estimated coefficients associated with age variables are employed to create the age-adjusted schooling measures evaluated at age $30^{5}$. As we see, there was an acceleration in the growth of average years of education of cohorts born after 1975.

\footnotetext{
${ }^{5}$ The processing of data follows DeLong, Goldin and Katz (2003), see notes of figure 2 in the paper.
} 
The change in the composition of workers' education levels across the wage distribution implies the possible decline in the average quality of the tertiary group. Figure 8 compares the composition of workers with different education levels at each $5^{\text {th }}$ percentile of the wage distribution in 1995 with that in 2013. As we see, there were few tertiary-educated workers receiving a wage lower than the median wage in 1995; however, $14.3 \%$ of the tertiary-educated workers received a wage lower than or equal to the median wage in 2013. This is consistent with the degraded tertiary hypothesis in that those new entrants with tertiary education but lower quality are paid less according to their actual quality level thus dragged down the average wage of the tertiary group. The average wage of the tertiary group would be higher than what we observed from the data without those people.

\section{The Impact of Supply and Demand:}

\subsection{The supply-demand framework}

Following Autor, Katz and Kearney (2008), assume that the CES production function takes the following form:

$$
Q_{t}=A_{t}\left(N_{U t}^{\rho}+\alpha_{t} N_{S t}^{\rho}\right)^{1 / \rho}
$$

in which $Q_{t}$ is total output at time $\mathrm{t}$, and $N_{U t}$ and $N_{S t}$ are the quantities of employment of unskilled and skilled labor at time t. $A_{t}$ is the skill-neutral technology change at time $t$, and the skill-biased technology change would increase $\alpha_{t}$, which is a measure of relative productivity of skilled workers over unskilled 
workers. The elasticity of substitution between skilled and unskilled labor equals $1 /(1-\rho)=\sigma$

By calculating the marginal product of skilled and unskilled labor, the relationship between relative wage and relative supply can be expressed by the following equation:

$$
\ln \left(w_{S t} / w_{U t}\right)=\ln \alpha_{t}-(1 / \sigma) \ln \left(N_{S t} / N_{U t}\right)=(1 / \sigma)\left[\ln D_{t}-\ln \left(N_{S t} / N_{U t}\right)\right]
$$

in which $\ln D_{t}=\ln \left(\alpha_{t}{ }^{\sigma}\right)$ represents the relative demand shifts due to skill-biased technology changes. The greater the elasticity of substitution $\sigma$ is, the smaller is the impact of change in the relative supply on the relative wage, and the greater is the change in the relative wage that should be accounted for by the demand change.

While empirically implementing this framework, a time trend and the log of the unemployment rate of male workers are used as measures of the demand change. The model specification is the following:

$\ln \left(w_{S t} / w_{U t}\right)=\beta_{0}+\beta_{1} t+\beta_{2} \ln \left(N_{S t} / N_{U t}\right)+\beta_{3} \ln \left(\right.$ Unemp $\left._{t}\right)+\varepsilon_{t}$

in which $1 / \beta_{2}$ is the estimate of elasticity of substitution $\sigma$.

In this analysis, the skilled group is workers with tertiary education $(12+$ years $)$ and the unskilled group refers to those with incomplete secondary education (5-10 years). Most of the results presented in the following are robust if utilizing the complete secondary group (11 years) as the reference group. In the case of less developed countries compared to the US, it is of interest to extend the two factor 
CES production function to include three factors. In Brazil, workers with primary or less education should still take a substantial proportion of the economically active people and there are significant variation in productivity among workers with primary, secondary and tertiary levels of education.

Considering that workers with the same education level but different experience levels are imperfect substitutes, it is expected that the relative supply of a specific age group would have a varying degree of impact on the tertiary premium of all age groups. Autor, Katz and Kearney (2008) also extend the previous equation (1) to account for changes in the relative supply of different groups with varying experience levels.

The extended model is the following:

$\ln \left(w_{S j t} / w_{U j t}\right)=\beta_{0}+\beta_{1} t+\beta_{2} \ln \left(N_{S t} / N_{U t}\right)+\beta_{3}\left[\ln \left(N_{S j t} / N_{U j t}\right)-\ln \left(N_{S t} / N_{U t}\right)\right]+$

$\beta_{4} \ln \left(\right.$ Unemp $\left._{t}\right)+E_{j}+\varepsilon_{t}$

in which $\mathrm{j}$ represents experience group $\mathrm{j}$ and $E_{j}$ is a set of dummies indicating the experience groups under analysis.

\subsection{The Role of Supply and Demand}

Following the approach presented in section 4.1, several regressions are run to see how supply and demand shifts affected the log educational differentials between 1995 and 2013. Between 1995 and 2004, we observed an increase in the tertiary premium and stable relative supply. The decline in the educational premium of the 
tertiary group between 2004 and 2013 coincided with a rise in the relative supply. Given these changes in price and supply, the market-clearing condition requires an increase in demand for tertiary-educated workers during 1995-2004 and a slower growth in relative demand compared to supply during 2004-2013.

Figure 9 depicts the detrended log relative supply and detrended log relative wage of workers with tertiary education with respect to those with incomplete secondary education. As we can see from the graph, the deviations in relative supply from a linear trend is negatively correlated with the changes in the detrended relative wage.

The results are shown in table 1, for overall samples as well as male and female subsamples. The log tertiary premium is regressed on the log relative supply, controlling demand shifts. In column 2 , the time trend and male unemployment rate are used as controls of the demand shift. The estimate associated with the log relative supply is -0.33 ; thus, the estimated elasticity of substitution equals 3 . The estimate of the time trend is positive and significant, which indicates an increase in the relative demand. As we noted from the previous statistical analysis, the relative supply during 1995-2004 did not change much, and the growth in the premium should be primarily accounted for by the shift in demand. This is proved by column 1, which documents the estimates of the 1995-2004 period and exhibits an insignificant impact of the relative supply and a significant and positive time trend. In columns 3 and 4 , we test whether there is an extraordinary pattern associated with the demand shift. First, we allow a break in 2004, and the results in column 3 demonstrate there was no significant decline in demand after 2004. Then, we add a 
quadratic term of the time trend, the results imply a slight slowdown of demand growth during the period. The same set of analyses are run for male and female subsamples, and the results are documented in columns 5-8 and columns 9-12, respectively. The results are all comparable with the results based on the total samples.

It is of interest to test whether the change in the tertiary premium varies across age groups. The regression results of equation 2 are documented in table 2. Columns 1 and 2 are the results when 4 experience groups (1-10 years, 11-20 years, 21-30 years and $31+$ years) are pooled, controlling for groups dummies, which shows the significant impact of both aggregate supply and group-specific supply changes. Columns 3-6 are the regression results of each experience group, which demonstrate the significant impact of the shift in the aggregate demand and the aggregate supply on the relative return. Those are also true for the male and female subsamples.

Based on the regression results, we can conclude that the increase in demand for workers with tertiary education is the main cause for the mild increase in the tertiary premium during 1995-2004. For the decline in the tertiary premium during 2004-2013, the fast increase in the relative supply is the main reason, although the relative demand was still increasing during this period, but it was not fast enough to digest all of the increase in the relative supply; thus, the premium declined. 


\section{The Degraded Tertiary Hypothesis:}

As stated in the previous paragraphs, the period of wage structure change coincides with education expansion in Brazil. As a result, the quality composition of the tertiary-educated workers might also have deteriorated, which is called the "degraded tertiary hypothesis" according to Lustig, Lopez-Calva and Ortiz-Juarez (2013). The change in the average quality of the tertiary group could also be a reason for the decline in the tertiary premium. Thus, a research question to be further explored is whether the expansion of tertiary education leads to a decline in the average quality of the tertiary group of the recent cohorts and to what extent the decline in the tertiary premium is accounted for by the change in the average quality.

Assume that there is a threshold of individuals' ability, where individuals above this threshold could benefit from education and individuals with ability below it cannot effectively learn the knowledge. If the education expansion goes beyond this threshold, there is a waste of resources. For education expansion not going beyond the threshold, it is beneficial to society from a welfare perspective because people with capability all get opportunities to develop themselves. Even if the expansion is completely beneficial, the average quality of the tertiary group might still be degraded. First, if most of the individuals admitted into college due to the expansion possess ability levels lower than the average level of the previously admitted group, and assuming one's quality growth due to college education is an increasing function of one's ability level, the average quality of the tertiary group might decrease; the possibility of decline in average quality is also positively related with 
the scope of the expansion. Second, when there are more students sharing the same amount of education resources, the quality growth of those previously admitted might be disturbed due to the dilution of resources. Thus, the decline in average quality of the tertiary group is also related to how the education expansion is implemented, whether there is sufficient and qualified support of resources.

\subsection{Datt-Ravallion Decomposition}

There are some consistent evidences of the "degraded tertiary hypothesis" shown in the previous paragraphs; one more supporting evidence could be generated by the Datt-Ravallion decomposition (Datt and Ravallion, 1992), which decomposes the change between two time periods of the proportion of individuals below a given threshold-- the "headcount ratio", into a parallel shift of the distribution (the "growth effect") and a change in the shape of the distribution (the "redistribution effect"). The following formula calculates the Shapley value of Datt-Ravallion decomposition as proposed by Shorrocks (2013) in which $C_{G}^{S}$ denotes the growth effect and $C_{R}^{S}$ denotes the redistribution effect, $\mathrm{H}$ refers to the headcount ratio which can be expresses as a function of average income $\mu$ and the Lorenz curve L. The Shapley Value approach of the D-R decomposition avoids the issues that the D-R is not an additive decomposition and it is path dependent.

$$
\left\{\begin{array}{c}
\Delta H=H\left(\mu_{1}, L_{1}\right)-H\left(\mu_{0}, L_{0}\right)=C_{G}^{S}+C_{R}^{S} \\
C_{G}^{S}=\frac{1}{2}\left[H\left(\mu_{1}, L_{0}\right)-H\left(\mu_{0}, L_{0}\right)+H\left(\mu_{1}, L_{1}\right)-H\left(\mu_{0}, L_{1}\right)\right] \\
C_{R}^{S}=\frac{1}{2}\left[H\left(\mu_{0}, L_{1}\right)-H\left(\mu_{0}, L_{0}\right)+H\left(\mu_{1}, L_{1}\right)-H\left(\mu_{1}, L_{0}\right)\right]
\end{array}\right.
$$


Table 5 presents the results of decomposing wage distributions of full-time male workers aged 25-65 with tertiary education (12+ years). In supporting the "degraded tertiary hypothesis", the D-R decomposition shows that there were more tertiary workers in 2013 earning a lower wage, which was caused by not only a left shift of the wage distribution but also an enlarged lower tail. As shown in table 5, when utilizing the average wage in 1995 of the male tertiary group as the threshold, the "headcount ratio" increased 12.39\% between 1995 and 2013, which could be decomposed into a $8.48 \%$ growth effect and a $3.92 \%$ re-distribution effect; if one employs the average wage in 2013 of this group as the threshold, the "headcount ratio" would have increased 15.34\% between 1995 and 2013, which could be decomposed into a $9.49 \%$ growth effect and a 5.85\% re-distribution effect.

\subsection{Identifying the Change in Average Ability}

Juhn, Kim and Vella (2005) make an inference about the change in the average quality of the tertiary group of the recent cohorts in the US from the change in the tertiary premium, controlling for other relevant variables. The approach employed here follows the idea of Juhn et al. (2005). The wage and supply samples analyzed in this section are males aged 25-65 with tertiary education, considering those aged 16-24 might not have finished their study yet. Table 6 presents the average hourly wage by birth cohort in each survey year of the samples under analysis. The variation along each column for different birth year cohorts in each specific year reflects both the return to experience and the change in the average quality, and it is always monotonically increasing. The variation along each row reflects both the 
return to experience and the impact of aggregate economic conditions for the same birth cohort. More importantly, along each diagonal line, it is the variation of the same age group that comprises different birth cohorts in different years. This variation along each diagonal line reflects both the change in the return to different cohorts and aggregate economic shocks. In addition, the difference across diagonal lines reflects the change in the return to different age groups. As we see, basically for every age group, the variation during the period is the same as the general trend, which declined during 1995-2004 and increased during 2004-2013.

The variation along and across diagonal lines shown above is employed for identifying the change in the average quality. Therefore, the dependent variable is the change in the relative return to tertiary workers of a specific age group between any two years, that is, $\Delta \log \left(\frac{w_{a T t}}{w_{a t}}\right)$, in which T indicates the tertiary group, a denotes the age group, and $t$ denotes year $t$. The regressor of primary interest is the change in the relative supply of tertiary workers within each age group, that is, $\Delta \log \left(\frac{N_{a T t}}{N_{a t}}\right)$. Because the variation along each diagonal line also reflects the aggregate economic shocks of each year, a set of year dummies should be controlled for. In addition, the variation among different diagonal lines reflects changes in the supply of tertiary workers across age groups, so it also controls for the size of each age group within the tertiary group, that is, $\Delta \log \left(\frac{N_{a T t}}{N_{T t}}\right)$, as well as for dummies for age groups (25-35 and 36-50 years old). The specification is the following:

$$
\Delta \log \left(W_{a T t} / W_{a t}\right)=\beta_{1} \Delta \log \left(N_{a T t} / N_{a t}\right)+\beta_{2} \Delta \log \left(N_{a T t} / N_{T t}\right)+D_{t}+D_{a}+\varepsilon_{a t}
$$


in which $D_{t}$ and $D_{a}$ are year dummies and age group dummies, respectively.

Figure 10 depicts the changes between 1995 and 2004 as well as between 2004 and 2013 in the log relative wage and the log share of male workers with tertiary education at different ages. Both graphs exhibit a negative correlation between changes in the relative wage and changes in the relative supply, and the negative correlation between 1995 and 2004 appears more obvious. For the following regressions, the changes in the $\log$ relative return $\Delta \log \left(W_{a T t} / W_{a t}\right), \log$ relative supply $\Delta \log \left(N_{a T t} / N_{a t}\right)$ and log relative size of each age group within the tertiary group $\Delta \log \left(N_{a T t} / N_{T t}\right)$ are differences taken between 1995 and 1997, 1997 and 1999, 1999 and 2001, 2001 and 2003, 2003 and 2005, 2005 and 2007, 2007 and 2009, 2009 and 2011 and between 2011 and 2013.

\subsection{Estimation results}

The regression results reported in table 7 demonstrate that after controlling for the increase in the relative supply, the tertiary premium of male workers of the recent cohorts is lower than that of the previous cohorts, which can be seen as evidence of the decline in cohort quality.

As we see from table 7, the coefficient of the tertiary share variable is negative and statistically significant. The results demonstrate that a $10 \%$ increase in the ratio of male workers with tertiary education would lower the tertiary premium by $3.1 \%$, cateris paribus. The regressions are also run separately for younger workers (25-35 years old) and older workers (36-65 years old) to see whether the cohort quality 
effect also varies with age. Column 2 of table 7 demonstrates that the impact of the cohort quality on the tertiary premium is no longer significant when analyzing younger samples (25-35 years old male), but the estimated impact is robust for the older samples (36-65 years old), as shown in column 3. This might be because the implicit assumption of this regression that workers with different ages are perfect substitutes for each other is more valid for older workers, which allows for separating the quality and quantity effects (Juhn et al., 2005).

\subsection{The contribution of the price effect and composition effect on change in tertiary premium}

Based on the cohort regression results in this session, the overall change in the tertiary premium during 1995-2013 could be decomposed into the change in the cohort quality and the price effect, which is an aggregation of the supply and demand shifts and macro-economic shocks. According to the data, the relative wage of male workers with tertiary education aged 25-65 declined by 36\% between 1995 and 2013, of which the increase in the share of the tertiary group contributed $24 \%$. The other $12 \%$ of the decline resulted from changes in supply and demand as well as from aggregate time effects.

\section{Conclusion}

Using PNAD 1995-2013 data, this paper presents the decline in wage inequality and changes in the wage structure in Brazil. One most notable change in the wage structure was the convergence in the educational differential in which the average wages of the tertiary group and the complete secondary group declined and the 
average wages of other education categories increased. The decline in the education premium also coincided with the education expansion. When analyzing changes in the relative wage and relative supply of the tertiary group with respect to those with incomplete secondary, we find that the growth in the relative demand was the main cause for the minor increase in the relative tertiary premium during the 1995-2004 period. For the decline in the relative return to tertiary-educated workers during the 2004-2013 period, it was because the sharp increase in the relative supply was faster than the increase in the relative demand. Then, the change in the average quality of the tertiary group as a possible consequence of the education expansion is further tested, and we find that the tertiary premium decreased while controlling for the impact of supply from which we make the inference that the average ability of the tertiary group declined.

When analyzing the impact of shifts in demand and supply on skill price, a two factor CES production model was adopted following Autor, Katz and Kearney (2008). However, this only allows us to compare workers with two education/skill levels, which fails to capture the entire variation across all education groups. A possible solution might be aggregating the unskilled groups by assuming a certain elasticity of substitution among them to capture all education/skill groups in one picture.

In addition, the analysis of the tertiary group and the change in the tertiary premium do not fully answer why there was a constant decline in wage inequality in Brazil between 1995 and 2013, although the stability of inequality within the tertiary group and the decline in inequality between the tertiary group and others 
account for it. If looking at the upper tail and lower tail of the wage distribution separately, we notice that between 1995 and 2013, the upper tail inequality measured by 90-50 log differential of the hourly wage is rather stable, but the lower tail inequality measured by 10-50 log differential declined continually, which means that to better understand the change in wage inequality in Brazil, it is also important to examine the changes at the lower tail, where the minimum wage might played a role. 


\section{References:}

1. Acemoglu, Daron, "Technical Change, Inequality and the Labor Market", Journal of Economic Literature, 2002, 40: 7-72.

2. Acemoglu, Daron and David H. Autor, "Skills, Tasks and Technologies: Implications for Employment and Earnings", 2011, in Handbook of Labor Economics Volume 4, Orley Ashenfelter and David E. Card (eds.), Amsterdam.

3. Autor, David H., "Skills, Education, and the Rise of Earnings Inequality Among the 'Other 99 Percent'”, Science, 2014, 344 (6186), 843-851.

4. Autor, David H., Lawrence F. Katz and Melissa S. Kearney, "Trends in US Wage Inequality: Revising the Revisionists", The Review of Economics and Statistics, 2008, 90(2): 300-323.

5. Barros, Ricardo, Mirela de Carvalho, Samuel Franco and Rosane Mendonca, "Markets, the States and the Dynamics of Inequality: The Case of Brazil", 2010, UNDP working paper.

6. Berger, Mark C., "The Effect of Cohort Size on Earning Growth: A ReExamination of the Evidence", Journal of Political Economy, 1985, 93: 561573.

7. Blackburn, McKinley L. and David Neumark, "Omitted-Ability Bias and the Increase in Return to Schooling", Journal of Labor Economics, 1993, 11: 521544.

8. Blom, Andreas, Lauritz Holm-Nielsen and Dorte Verner, "Education, earnings, and inequality in Brazil, 1982-98 - implications for education policy," 2001, Policy Research Working Paper Series 2686, The World Bank.

9. Campos-Vazquez, Raymundo, Luis F. Lopez-Calva and Nora Lustig, "Declining Wages for College-Educated Workers in Mexico: Degraded Tertiary or Skills Obsolescence?", 2014, Tulane Economics Working Paper.

10. Card, David and Thomas Lemieux, "Can Falling Supply Explain the Rising Return to College for Young Men?", Quarterly Journal of Economics, 2001, 116: 705-746. 
11. Carneiro, Pedro and Sokbae Lee, "Trends in Quality-Adjusted Skill Premia in the United States, 1960-2000", American Economic Review, 2011, Vol. 101(6): 2309-2349.

12. Datt, Gaurav and Martin Ravallion, "Growth and Redistribution Components of Changes in Poverty Measures: A Decomposition with Applications to Brazil and India in the 1980s", Journal of Development Economics, 1992, Vol. 38(2): 275-295.

13. Delong, Bradford, Claudia Goldin and Lawrence Katz, "Sustaining U.S. Economic Growth", in Agenda for the Nation, Aaron HJ, Lindsay JM, Nivola PS (eds), Washington, D.C.: The Brookings Institution, 2003, pp. 17-60.

14. Ferreira, Francisco H. G. and Ricardo Paes de Barros, "The Slippery Slope, Explaining the Increase in Extreme Poverty in Urban Brazil, 1976-1996", 1999, World Bank Policy Research Working Paper 2210.

15. Ferreira, Francisco H. G., Sergio P. Firpo and Julian Messina, "A more level playing field? Explaining the decline in earnings inequality in Brazil, 19952012", 2015, Brooks World Poverty Institute Working Paper Series iriba_wp12.

16. Ferreira, Francisco H. G., Phillippe G. Leite and Julie A. Litchfield, "The Rise and Fall of Brazilian Inequality: 1981-2004", 2008, Macroeconomic Dynamics, Cambridge University Press, vol. 12(S2), 199-230.

17. Ferreira, Francisco H. G., Phillippe G. Leite and Matthew Wai-Poi, "Trade liberalization, employment flows, and wage inequality in Brazil", 2007, World Bank Policy Research Working Paper 4108.

18. Green, Francis, Andy Dickerson and Jorge Saba Arbache, "A Picture of Wage Inequality and the Allocation of Labor Through a Period of Trade Liberalization: The Case of Brazil", World Development, Elsevier, 2001, vol. 29(11), 1923-1939.

19. Goldin, Claudia and Lawrence F. Katz, "The Race between Education and Technology: The Evolution of US Educational Wage Differentials, 1890-2005", 2007, NBER Working Papers NO. 12984. 
20. Holm-Nielsen, B., and Verner, "Education, Earnings and Inequality in Brazil 1982-1989: Implications for Education Policy", 2001, The World Bank.

21. Juhn, Chinhui, Dae Il Kim and Francis Vella, "The Expansion of College Education in the U.S. 1940-1990: Is There Evidence of Declining Cohort Quality?", Economic Inquiry, 2005, Vol. 43. 303-315.

22. Juhn, Chinhui, Kevin M. Murphy and Brooks Pierce, "Wage Inequality and the Rise in Returns to Skills", Journal of Political Economy, 1993, 101: 410-442.

23. Katz, Lawrence F. and David H. Autor, "Changes in the Wage Structure and Earning Inequality", in O. Ashenfelter and D. Card (Eds.), Handbook of Labor Economics, Vol. 3, Amsterdam: North-Holland, 1999.

24. Katz, Lawrence F. and Kevin M. Murphy, "Changes in Relative Wages 1963-87: Supply and Demand Factors", Quarterly Journal of Economics, 1992, 107: 3578.

25. Lemieux, Thomas, "Post-Secondary Education and Increasing Wage Inequality", 2006, NBER Working Paper NO. 12077.

26. Lustig, Nora, Lopez-Calva, Luis F. and Ortiz-Juarez, Eduardo, "Declining Inequality in Latin America in the 2000s: The Cases of Argentina, Brazil, and Mexico", World Development, 2013, 44(C): 129-141.

27. Lustig, Nora, Lopez-Calva, Luis F. and Ortiz-Juarez, Eduardo, "The Decline in Inequality in Latin America: How Much, Since When and Why", 2011, Working Papers 1118, Tulane University, Department of Economics.

28. Manacorda, Marco, Carolina Sanchez-Paramo and Norbert Schady, "Changes in Returns to Education in Latin America: the Role of Demand and Supply of Skills", 2005, CEP Discussion Papers dp0712, Centre for Economic Performance, LSE.

29. Piketty, Thomas and Emmanuel Saez, "Income Inequality in the United States, 1913-1998", Quarterly Journal of Economics, 2003, 118: 1-39.

30. Shorrocks, Anthony F., "Decomposition Procedures for Distributional Analysis: A Unified Framework based on The Shapley Value", Journal of Economic Inequality, 2013, 11: 99-126. 
31. Taubman, Paul and Terence Wales, "Mental Ability and Higher Educational Attainment in the 20s Centry", 1972, NBER and Carnegie Commission on Higher Education. 


\section{Data Appendix:}

While analyzing the impact of shifts in supply and demand, the relative return is composition-adjusted, which is for a fixed composition of workers--the average composition over the 1995-2013 period; thus, the changes in premium only reflect the change in wage structure but not changes in the composition of worker's characteristics. In correspondence, the relative supply measure is in efficiency units. This is a convention for analyzing the impact of supply and demand on relative wages, see Katz and Murphy (1992), DeLong, Goldin and Katz (2003), Acemoglu and Autor (2010), Autor (2014), Goldin and Katz (2007), and Autor, Katz and Kearney (2008), etc. The data are processed following the procedures described below (Autor, Katz and Kearney, 2008) to obtain the compositionadjusted relative wage measure and relative supply measure in efficiency units.

\section{To calculate composition-adjusted wage measures:}

1) Sort samples of each year into 40 groups defined by gender (male and female), education (incomplete primary, complete primary, incomplete secondary, complete secondary, tertiary) and experience levels (1-10, 11-20, 21-30 and 31+ year);

2) Separately by gender and for each year, the log hourly wage is regressed on 4 education dummies, a quartic of experience and a white dummy;

3) The average log hourly wage of each of the 40 groups in a given year is the predicted wage evaluated for whites, at the relevant experience levels $(5,15,25,35$ for each corresponding experience group);

4) The average log hourly wage for any broader group in each year represents weighted averages of the relevant groups utilizing a fixed set of weights that are equal to the mean share of total hours worked by each group during the 1995 to 2013 period from the "supply samples".

\section{To calculate supply measure in efficiency units:}

1) Based on the "Supply Samples", total hours worked per month of the 40 groups defined by gender, education and experience levels are calculated;

2) Employing the "Wage Samples", the average hourly wage of each of the 40 cells in each year is generated, which is then normalized to be in relative terms by dividing each measure by the average wage of a reference group, say male workers with incomplete secondary education and 11-20 years of experience in each corresponding year (the choice of the base group is harmless);

3) Compute the "efficiency unit" measure for each cell as the arithmetic mean of the normalized wage measures of that cell during 1995-2013;

4) The efficiency unit of labor supply of each cell in year t equals the "efficiency unit" wage measure of the cell times the quantity of labor supply of that cell in year $t$;

5) Calculate the aggregate supplies of the tertiary and incomplete secondary groups in each year; then, the log relative supply in each year can be generated. 
Figure 1: Wage Inequality: Total Samples, 1995-2013

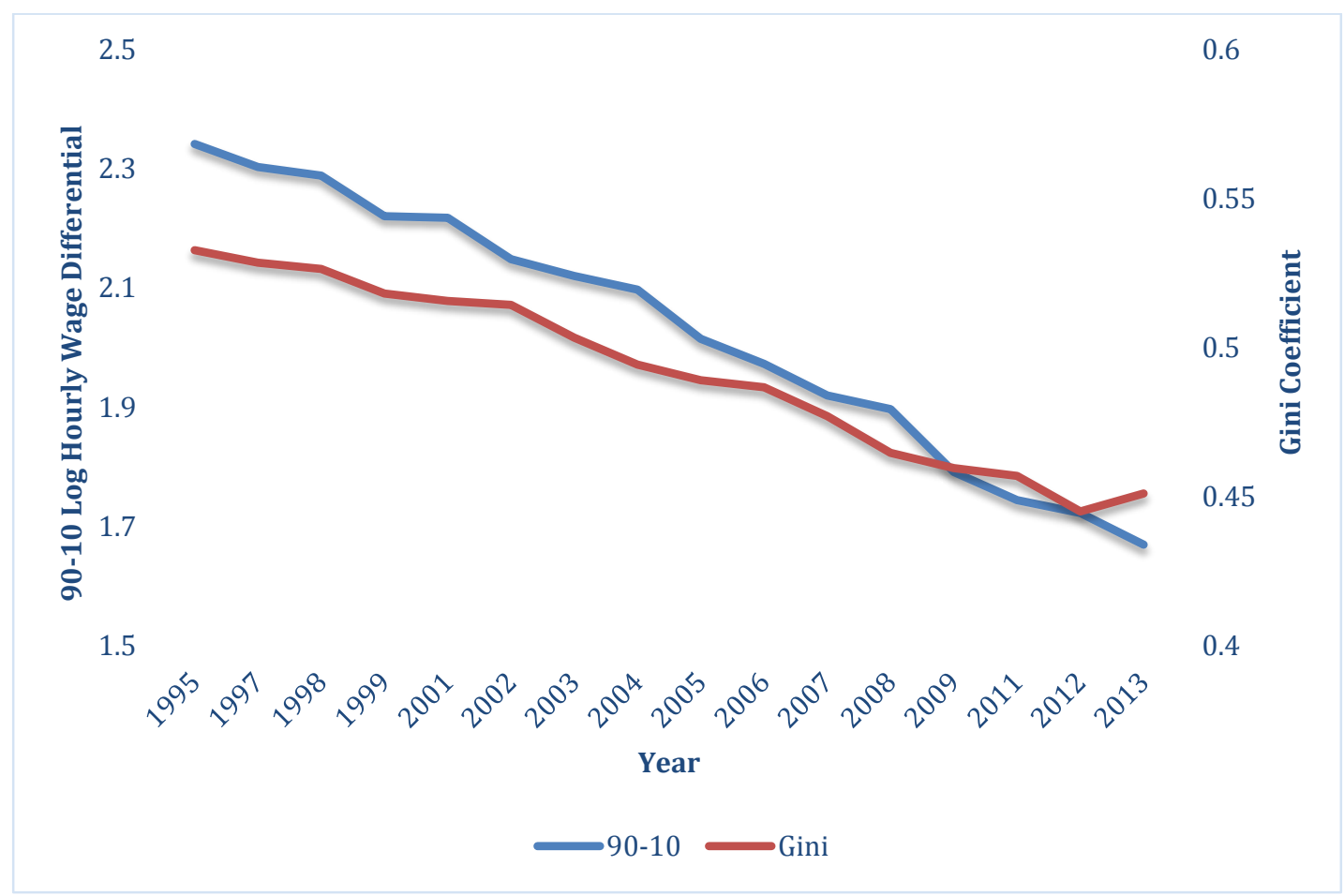

Note: Wage inequality is measured by the 90-10 log differential and Gini coefficient of hourly wage, which are calculated based on full-time workers aged between 16 and 65 from the PNAD 1995-2013 data. The sample of each group defined by gender, education level and year is trimmed at the $1^{\text {st }}$ and $99^{\text {th }}$ percentiles. 
Figure 2: 90-10 Log Hourly Wage Differential:

Total Samples, by Education Level, 1995-2013

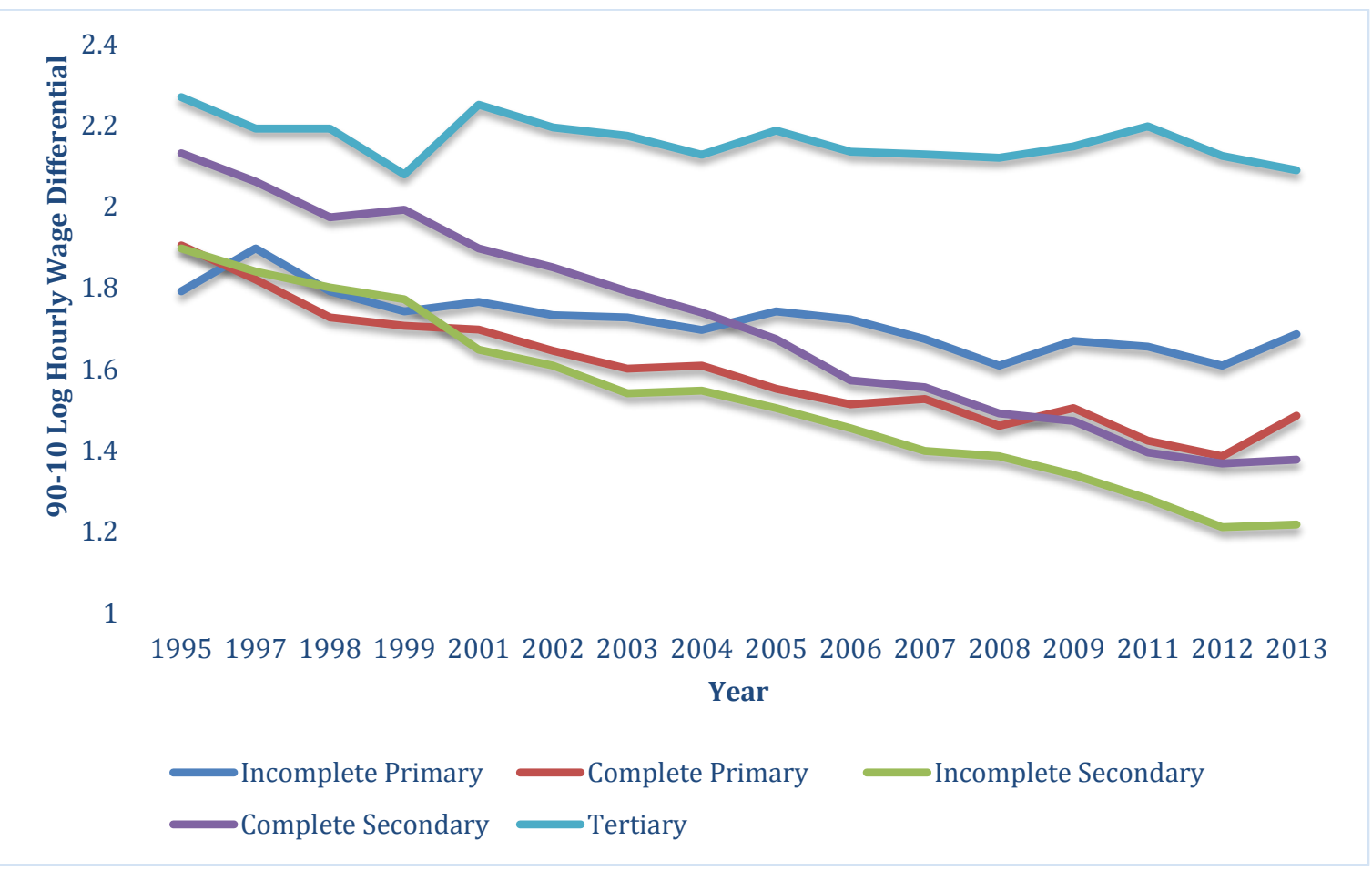

Note: Wage inequality is measured by the 90-10 log differential of hourly wage, which is calculated based on full-time workers aged between 16 and 65 from the PNAD 1995-2013 data. The sample of each group defined by gender, education level and year is trimmed at the 1st and 99th percentiles. The incomplete primary education group includes all of those with 0-3 years of education, the complete primary education group includes all of those with 4 years education, the incomplete secondary education group includes all those with 5-10 years of education, the complete secondary education group includes all of those with 11 years of education, and the tertiary education group includes all of those with $12+$ years of education. 
Figure 3: Average Hourly Wage

Full-Time Workers Aged 16-65, 1995-2013

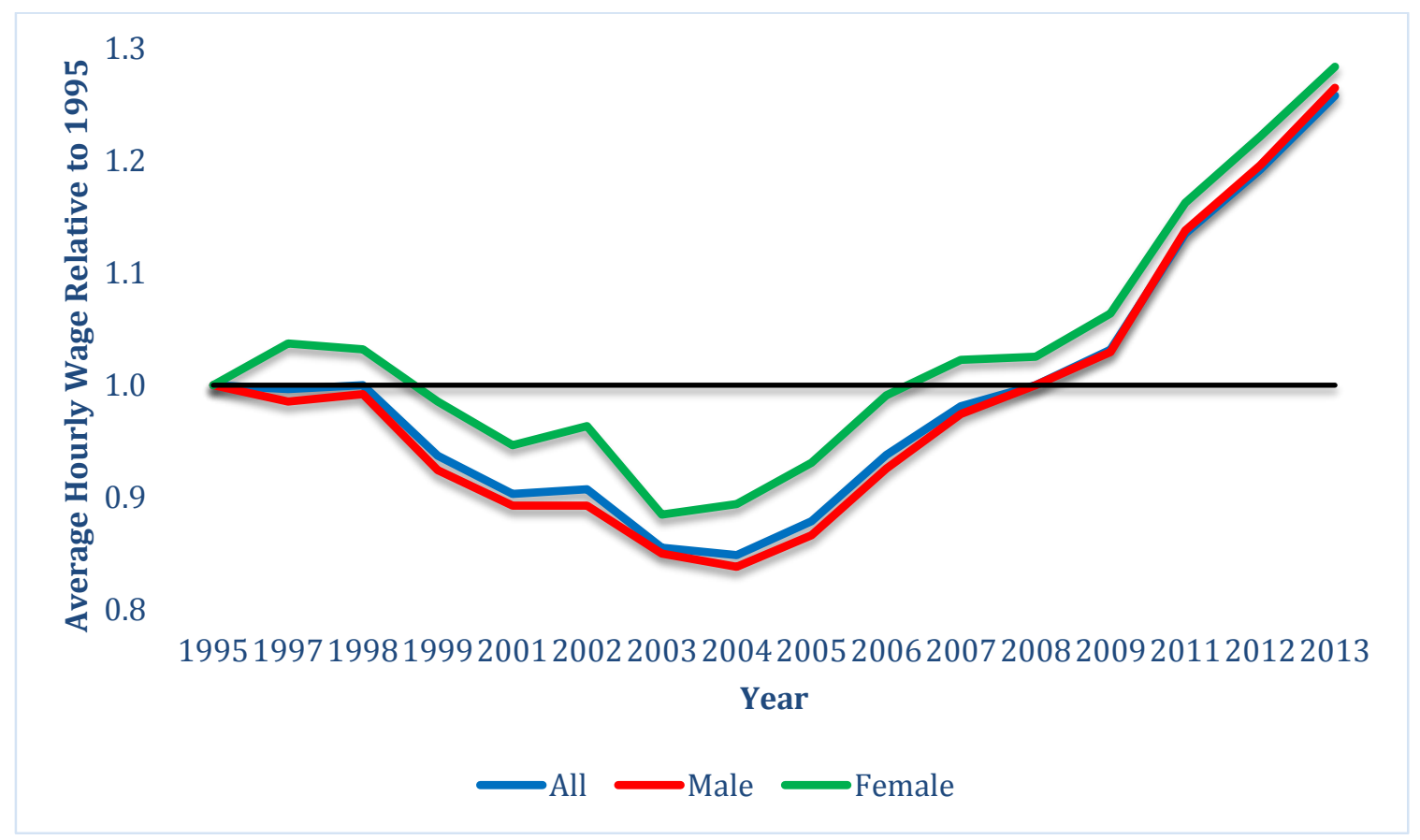

Note: Calculated based on full-time workers aged between 16 and 65 from the PNAD 1995-2013 data. The sample of each group defined by gender, education level and year is trimmed at the 1st and 99th percentiles. The wage measure is in constant 1995 prices. 
Figure 4: Average Hourly Wage by Education Group:

All Full-Time Workers Aged 16-65, 1995-2013

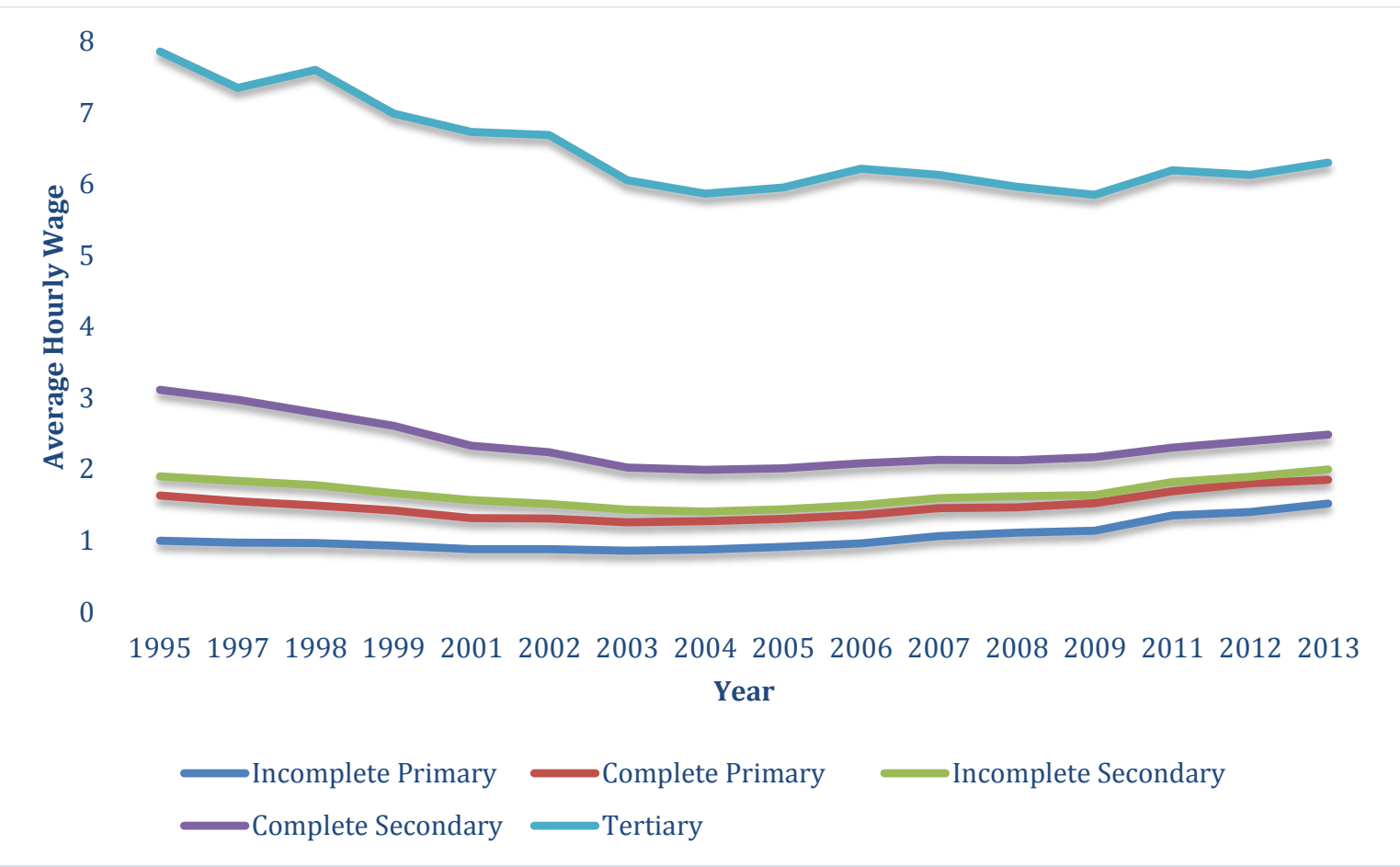

Note: Calculated based on full-time workers aged between 16 and 65 from the PNAD 1995-2013 data. The sample of each group defined by gender, education level and year is trimmed at the 1st and 99th percentiles. The incomplete primary education group includes all of those with 0-3 years of education, the complete primary education group includes all of those with 4 years education, the incomplete secondary education group includes all of those with 5-10 years of education, the complete secondary education group includes all of those with 11 years of education, and the tertiary education group includes all of those with $12+$ years of education. Wage measure is in constant 1995 prices. 


\section{Figure 5: Tertiary/Incomplete Secondary Hourly Wage Premium (Composition Adjusted)}

\section{All Workers Aged 16-65, 1995-2013}

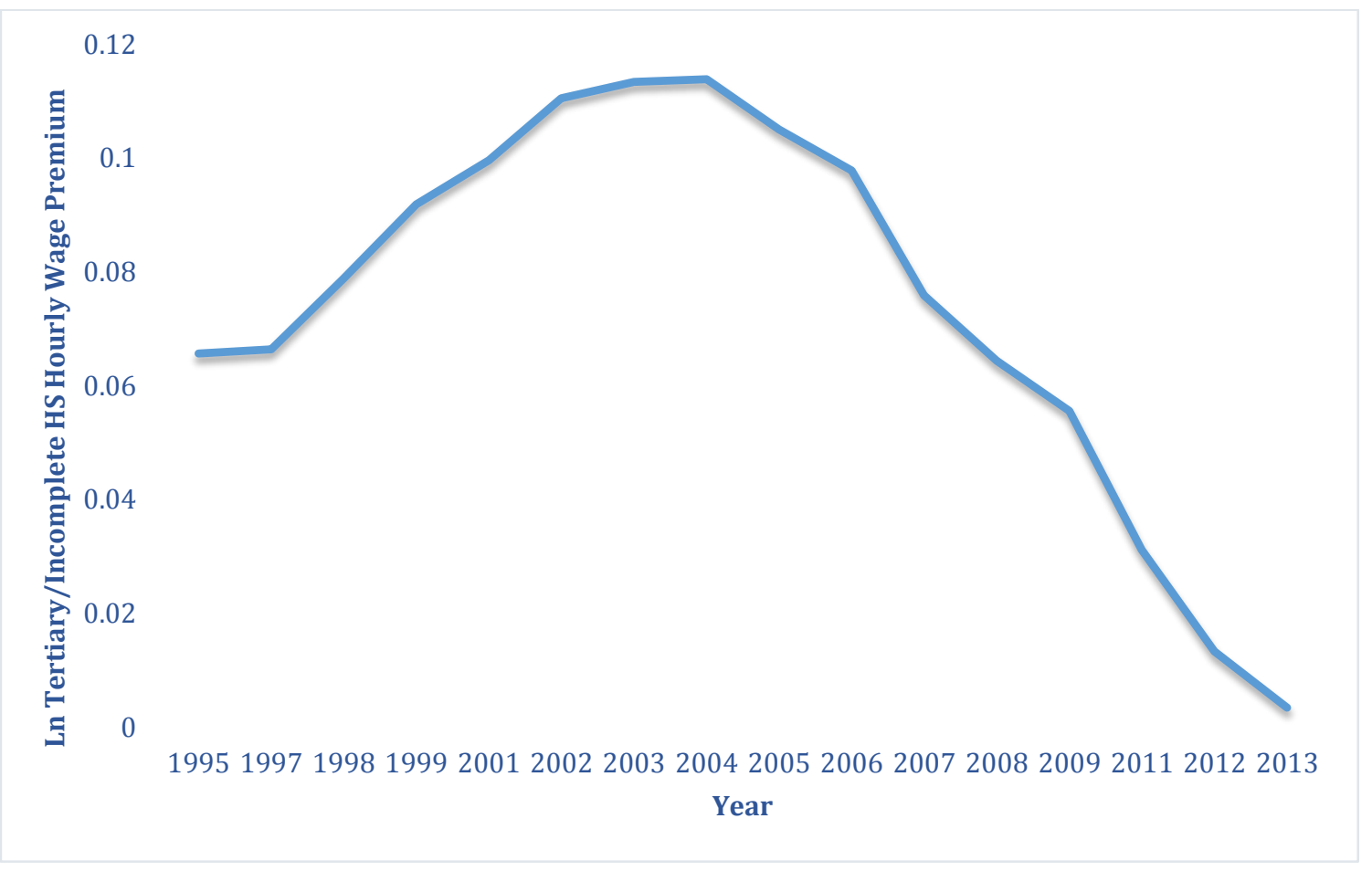

Note: Generated based on all full-time (worked at least 140 hours in the survey month) workers (employers, employees and the self-employed) aged between 16 and 65 from the 1995-2013 PNAD surveys. The tertiary group includes those with $12+$ years of education (incomplete and complete college as well as those with graduate study), and the incomplete secondary group are those with 5-10 years of education. The wage premium is composition-adjusted, which means that the tertiary premium is for a fixed composition of workers--the average composition over the 1995-2013 period; thus, the changes in wage reflect only the change in wage structure but not changes in the composition of workers' characteristics. 
Figure 6: Log Relative Supply: Tertiary/Incomplete Secondary

All Workers Aged 16-65, 1995-2013

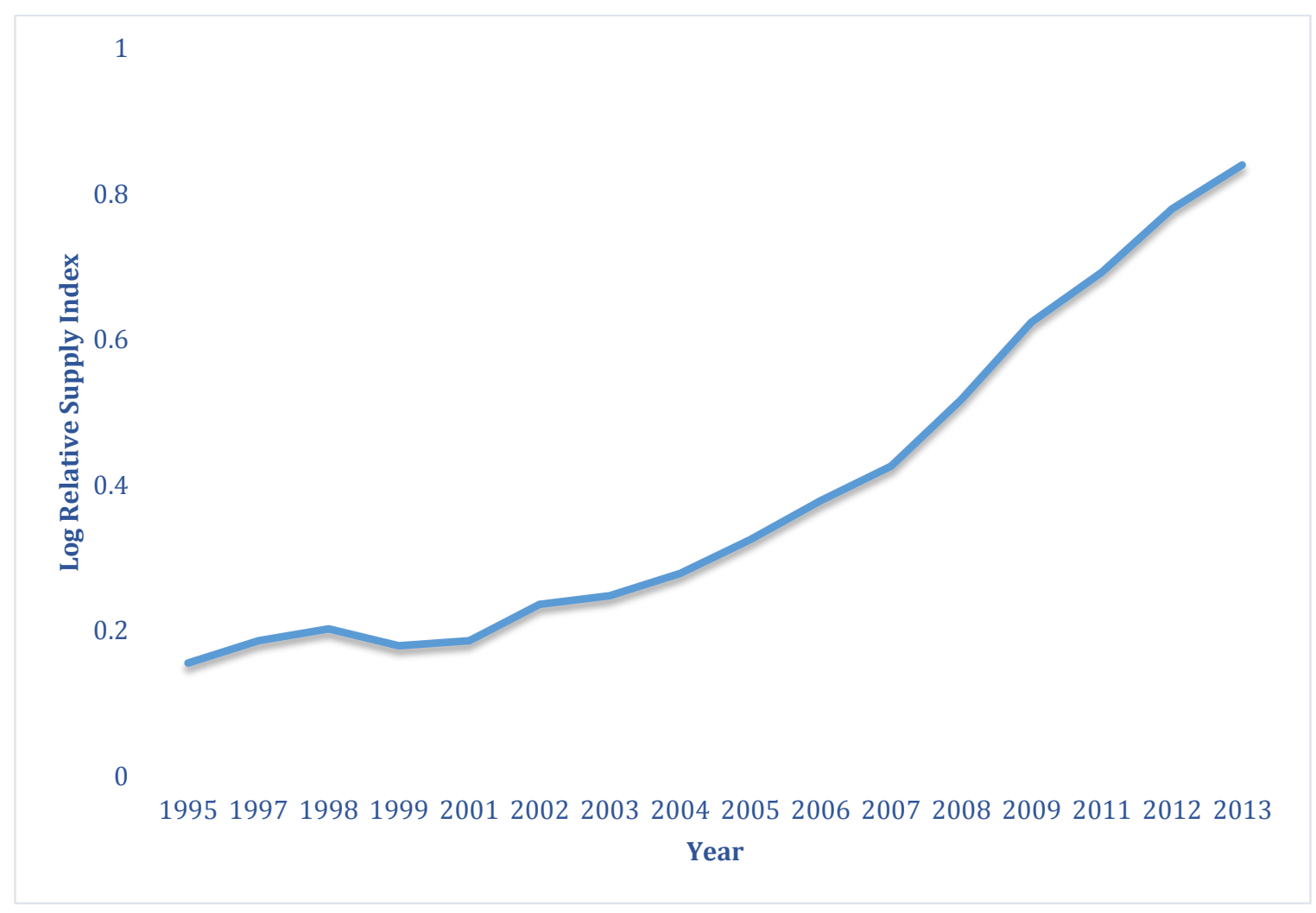

Note: All workers (supply samples include employers, employees, self-employed and domestic workers who worked at least 1 hour in the survey month) aged between 16 and 65 in the 1995-2013 PNAD surveys. The tertiary group includes those with 12+ years of education (incomplete and complete college as well as those with graduate study) and the incomplete secondary group are those with 5-10 years of education. 
Figure 7: By Birth Cohort: Average Years of Schooling at Age 30,

Workers Aged 16-65, Cohorts 1932-1994

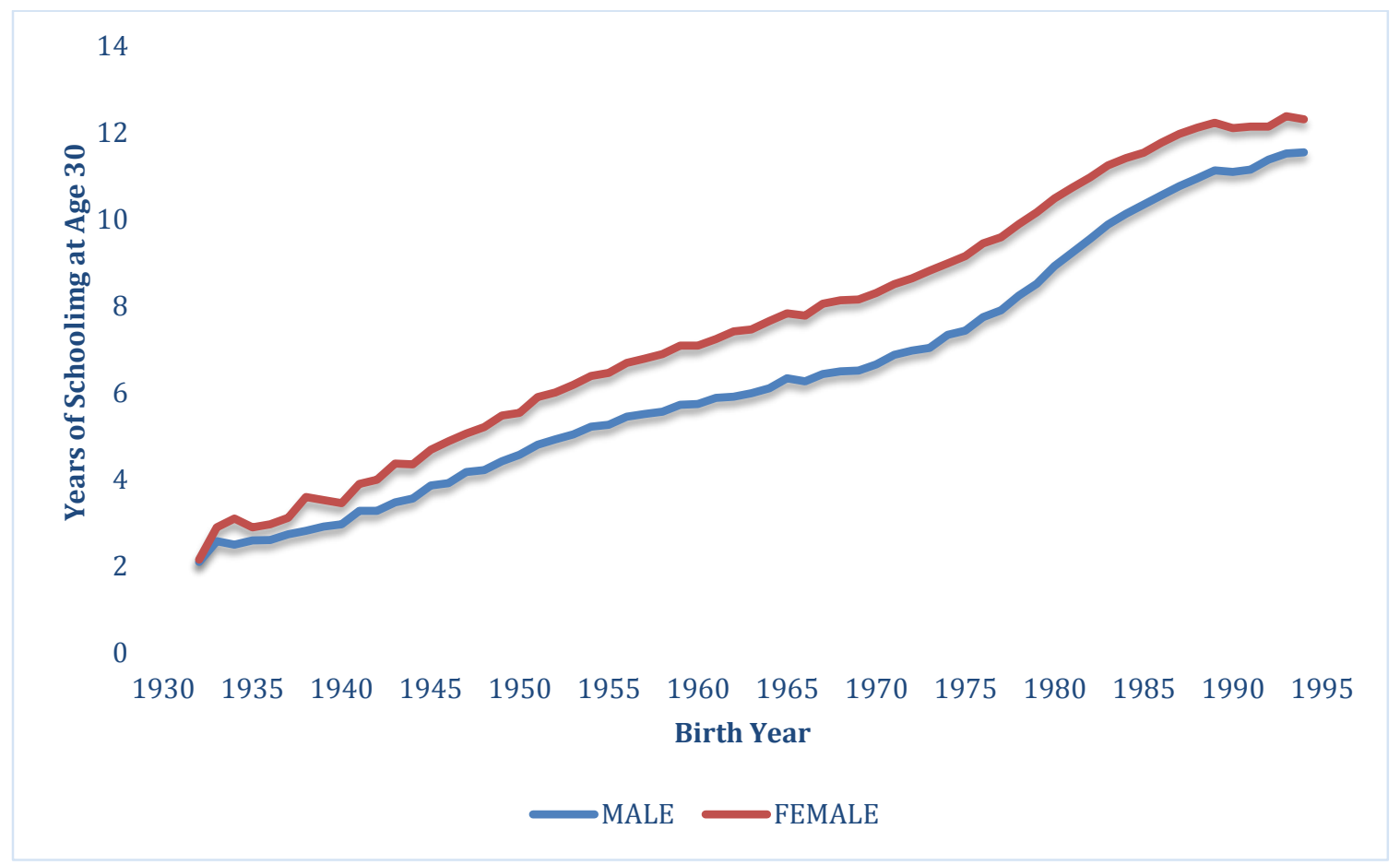

Note: All male/female workers (supply samples include employers, employees, the self-employed and domestic workers who worked at least 1 hour in the survey month) aged between 16 and 65 in the 1995-2013 PNAD surveys (which covers those born between 1932 and 1994) are polled together; then, the male/female samples are grouped into birth year-age cells. The log of average years of education in each cell is regressed on a set of birth year dummies and a quartic in age (Rsquared for both male and female regressions are above 0.9), and then, the estimated coefficients associated with the age variables are employed to create the age-adjusted schooling measures evaluated at age 30 . 
Figure 8: Education Composition at Each $5^{\text {th }}$ Percentile of Wage Distribution

a. Year 1995

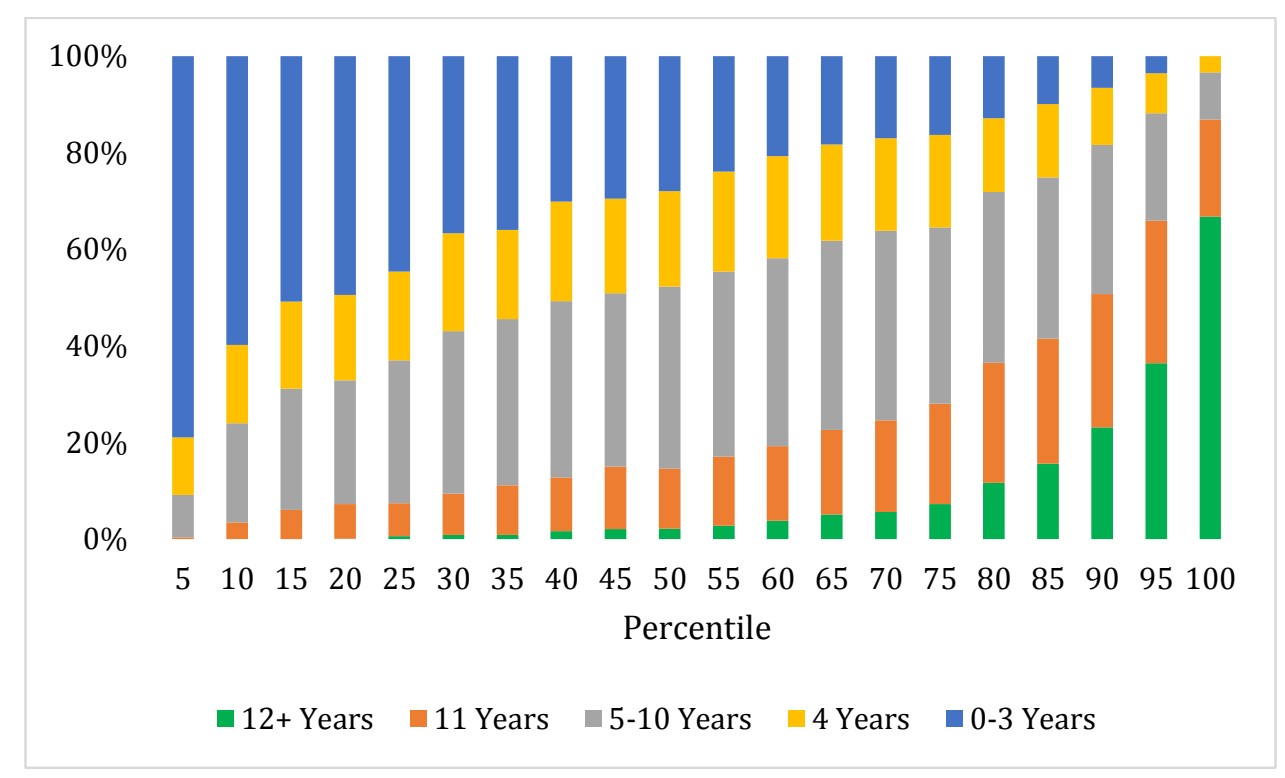

b. Year 2013

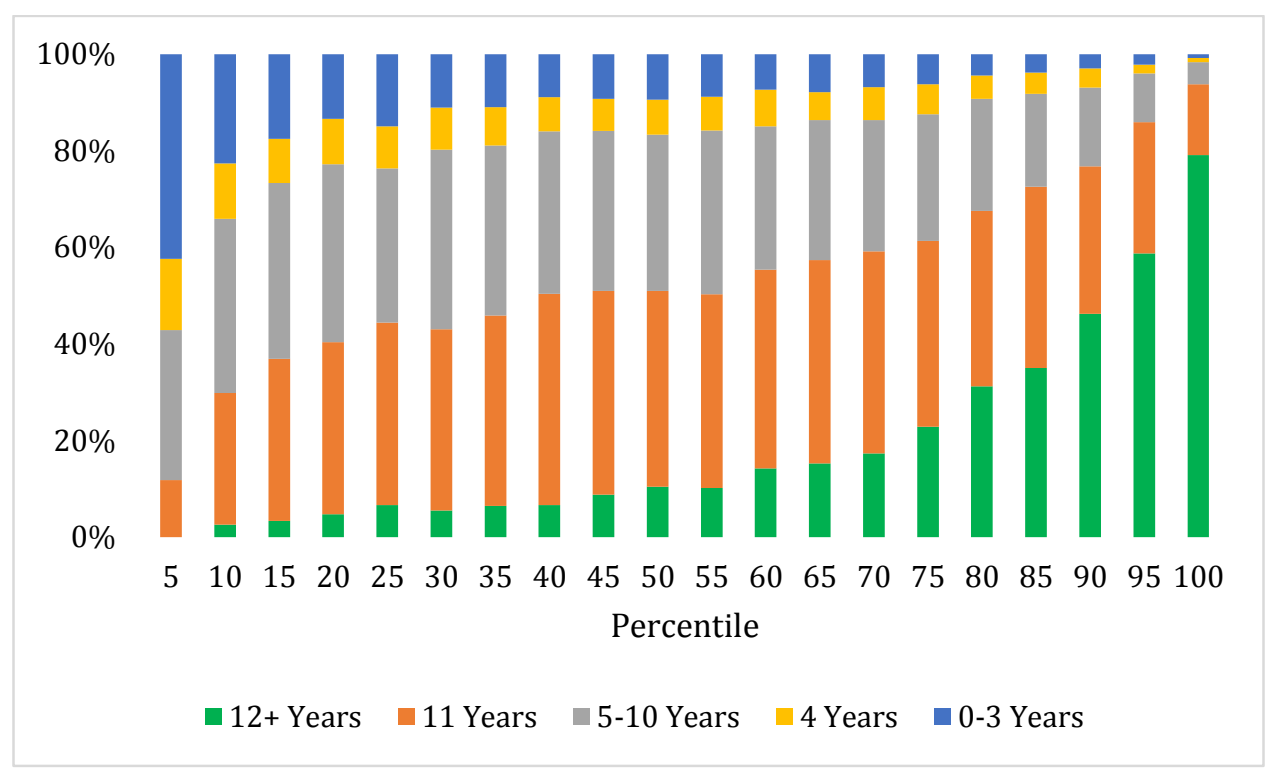

Note: Generated based on male full-time (worked at least 140 hours in the survey month) workers (employers, employees and the self-employed) aged between 16 and 65 from the 1995-2013 PNAD surveys. 


\section{Figure 9: Detrended Relative Wage Differential and Relative Supply: \\ All Samples Aged 16-65}

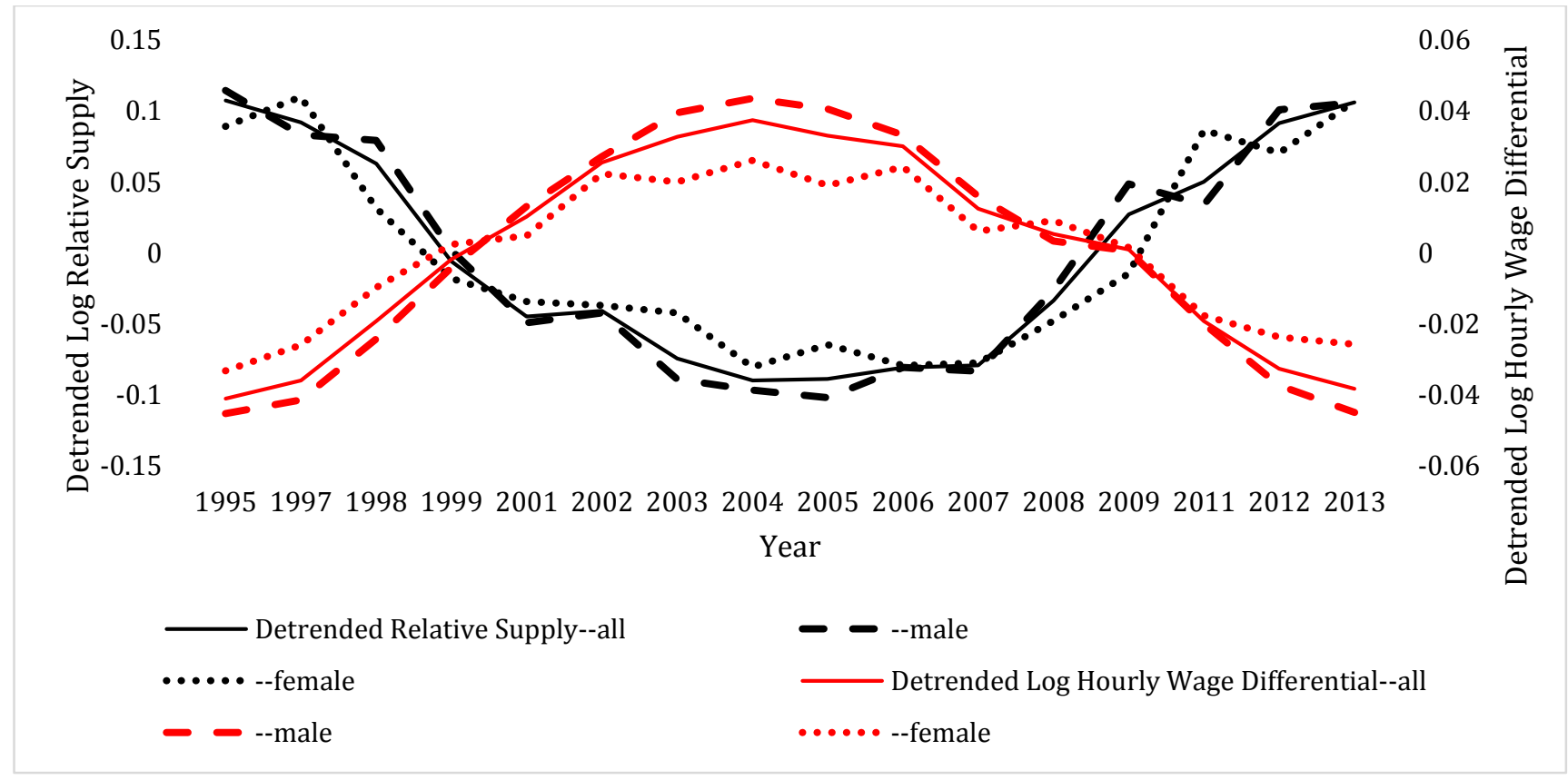

Note: The relative wage measure is the composition-adjusted log hourly wage of the tertiary group with respect to incomplete secondary workers. The log relative supply is log monthly hours worked in efficiency units of the tertiary group with respect to the incomplete secondary group. 
Figure 10: Change in Log Relative Wage and Log Tertiary Share:

a. Males Aged 25-65, 1995 vs. 2004

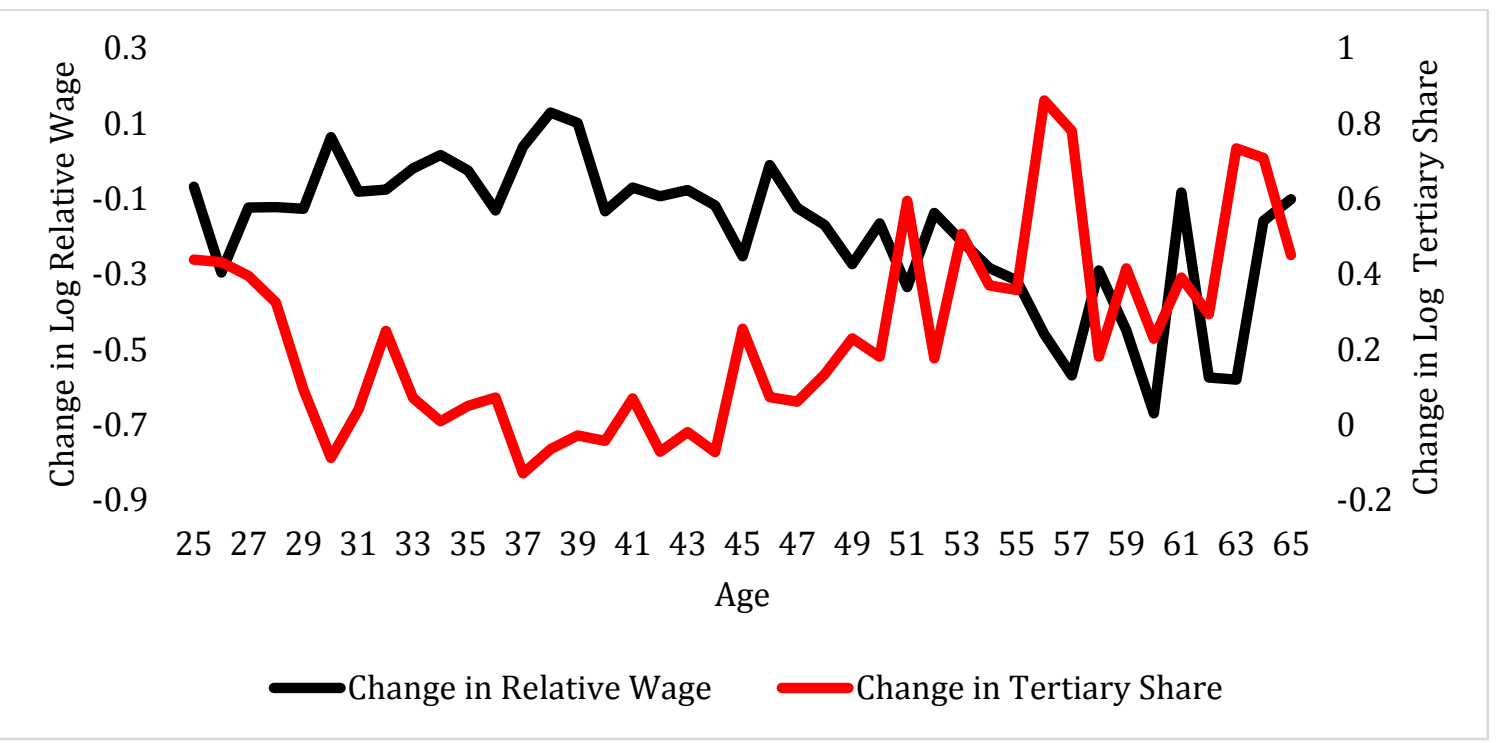

Note: The change in log relative wage is generated based on the wage samples from the PNAD 1995 and 2004 data, and the change in log tertiary share is generated based on the supply samples from the PNAD 1995 and 2004 data.

b. Males Aged 25-65, 2004 vs. 2013

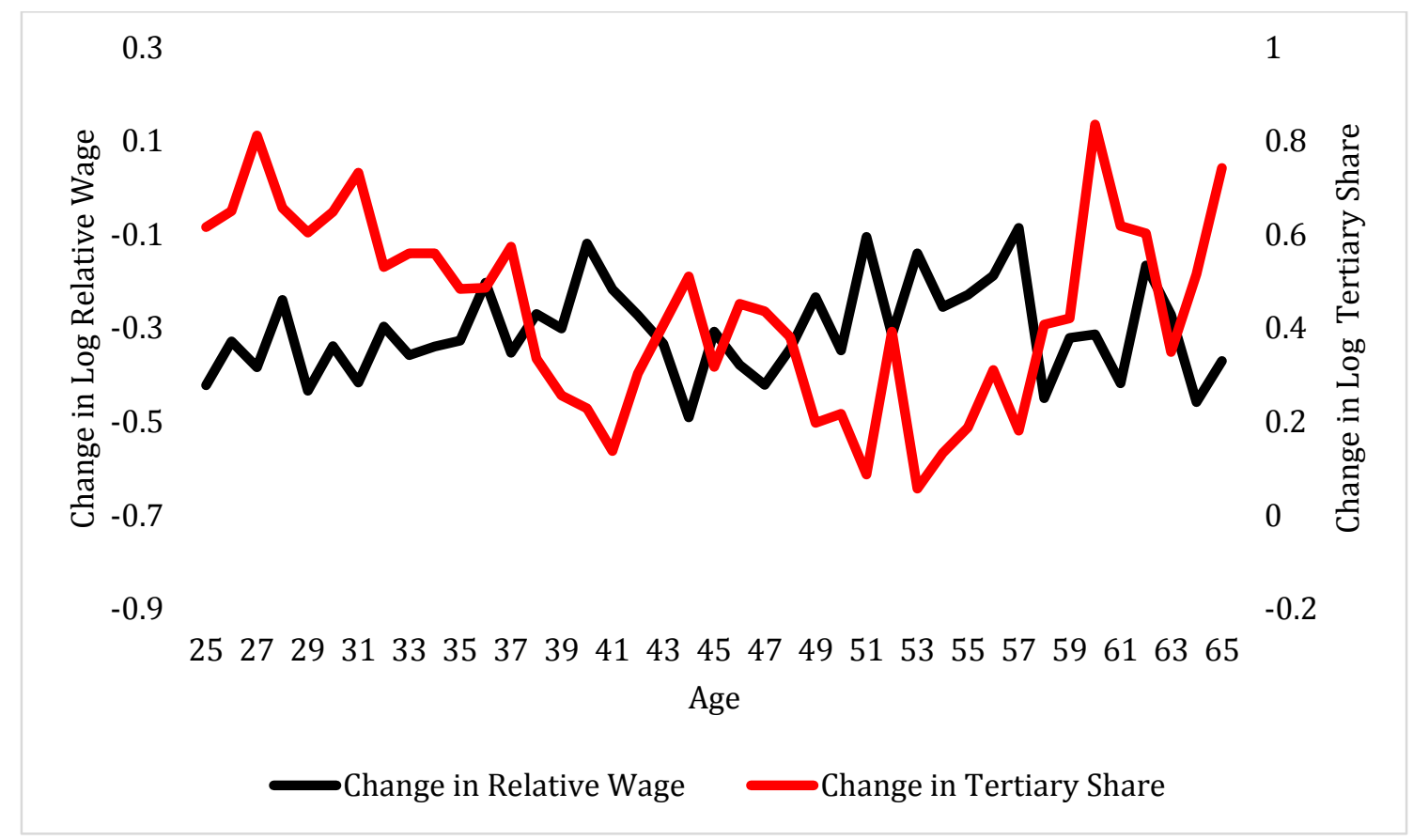

Note: The change in log relative wage is generated based on the wage samples from the PNAD 2004 and 2013 data, and the change in log tertiary share is generated based on the supply samples from the PNAD 2004 and 2013 data. 
Table 1

Determinants of Tertiary Wage Premium: Workers Aged 16-65

\begin{tabular}{|c|c|c|c|c|c|c|c|c|c|c|c|c|}
\hline & \multicolumn{4}{|c|}{ Pooled Samples } & \multicolumn{4}{|c|}{ Male Samples } & \multicolumn{4}{|c|}{ Female Samples } \\
\hline & (1) & $(2)$ & (3) & (4) & (5) & $(6)$ & (7) & (8) & (9) & (10) & (11) & (12) \\
\hline & 1995-2004 & & $1995-201$ & & 1995-2004 & & 1995-201 & & 1995-2004 & & $1995-201$ & \\
\hline $\begin{array}{l}\text { Tertiary/Incomplete } \\
\text { Secondary Supply }\end{array}$ & $\begin{array}{c}-0.144 \\
(-0.104)\end{array}$ & $\begin{array}{c}-0.333^{* * *} \\
(0.031)\end{array}$ & $\begin{array}{c}-0.339 * * * \\
(0.035)\end{array}$ & $\begin{array}{l}-0.160 \\
(0.09)\end{array}$ & $\begin{array}{l}-0.156 \\
(0.11)\end{array}$ & $\begin{array}{c}-0.362^{* * *} \\
(0.039)\end{array}$ & $\begin{array}{c}-0.365^{* * *} \\
(0.044)\end{array}$ & $\begin{array}{l}-0.162^{*} \\
(0.083)\end{array}$ & $\begin{array}{c}-0.1 \\
(0.078)\end{array}$ & $\begin{array}{c}-0.232^{* * *} \\
(0.028)\end{array}$ & $\begin{array}{c}-0.236^{* * *} \\
(0.031)\end{array}$ & $\begin{array}{l}-0.095 \\
(0.059)\end{array}$ \\
\hline Time Trend & $\begin{array}{c}0.01^{* *} \\
(0.003)\end{array}$ & $\begin{array}{c}0.011^{* * *} \\
(0.002)\end{array}$ & $\begin{array}{l}0.012^{* * *} \\
(0.003)\end{array}$ & $\begin{array}{c}0.015^{* * *} \\
(0.003)\end{array}$ & $\begin{array}{c}0.011^{* * *} \\
(0.002)\end{array}$ & $\begin{array}{l}0.009^{* * *} \\
(0.002)\end{array}$ & $\begin{array}{c}0.01^{* *} \\
(0.004)\end{array}$ & $\begin{array}{c}0.017^{* * *} \\
(0.003)\end{array}$ & $\begin{array}{c}0.006 \\
(0.003)\end{array}$ & $\begin{array}{c}0.008^{* * *} \\
(0.002)\end{array}$ & $\begin{array}{l}0.009 * * \\
(0.003)\end{array}$ & $\begin{array}{l}0.01^{* * *} \\
(0.002)\end{array}$ \\
\hline $\mathrm{Time}^{\wedge} 2$ & & & & $\begin{array}{c}-0.001^{*} \\
(0.0003)\end{array}$ & & & & $\begin{array}{l}-0.001^{* *} \\
(0.0003)\end{array}$ & & & & $\begin{array}{c}-0.0006^{* *} \\
(0.0002)\end{array}$ \\
\hline Time*After 2004 & & & $\begin{array}{l}-0.0006 \\
(0.001)\end{array}$ & & & & $\begin{array}{l}-0.0003 \\
(0.002)\end{array}$ & & & & $\begin{array}{l}-0.0004 \\
(0.001)\end{array}$ & \\
\hline $\begin{array}{r}\text { Male Unemployment } \\
\text { Rate }\end{array}$ & $\begin{array}{l}-0.115 \\
(0.218)\end{array}$ & $\begin{array}{l}-0.282 \\
(0.225)\end{array}$ & $\begin{array}{l}-0.179 \\
(0.352)\end{array}$ & $\begin{array}{l}-0.210 \\
(0.204)\end{array}$ & $\begin{array}{l}-0.071 \\
(0.254)\end{array}$ & $\begin{array}{l}-0.282 \\
(0.298)\end{array}$ & $\begin{array}{l}-0.223 \\
(0.466)\end{array}$ & $\begin{array}{l}-0.178 \\
(0.248)\end{array}$ & $\begin{array}{l}-0.256 \\
(0.222)\end{array}$ & $\begin{array}{c}-0.441^{* *} \\
(0.186)\end{array}$ & $\begin{array}{l}-0.362 \\
(0.296)\end{array}$ & $\begin{array}{l}-0.258 \\
(0.172)\end{array}$ \\
\hline Constant & $\begin{array}{c}0.058 \\
(0.044)\end{array}$ & $\begin{array}{l}0.062 \\
(0.04)\end{array}$ & $\begin{array}{c}0.078 \\
(0.059)\end{array}$ & $\begin{array}{c}0.038 \\
(0.038)\end{array}$ & $\begin{array}{c}-0.015 \\
(0.043)\end{array}$ & $\begin{array}{c}-0.038 \\
(0.051)\end{array}$ & $\begin{array}{l}-0.029 \\
(0.074)\end{array}$ & $\begin{array}{c}-0.042 \\
(0.042)\end{array}$ & $\begin{array}{l}0.178^{* *} \\
(0.055)\end{array}$ & $\begin{array}{c}0.208^{* * *} \\
(0.039)\end{array}$ & $\begin{array}{c}0.221^{* * *} \\
(0.056)\end{array}$ & $\begin{array}{c}0.170^{* * *} \\
(0.036)\end{array}$ \\
\hline Obs. & 8 & 16 & 16 & 16 & 8 & 16 & 16 & 16 & 8 & 16 & 16 & 16 \\
\hline R-squared & 0.974 & 0.967 & 0.967 & 0.976 & 0.975 & 0.952 & 0.952 & 0.97 & 0.904 & 0.965 & 0.965 & 0.978 \\
\hline
\end{tabular}

Note: Regression based on samples generated from PNAD 1995-2013 data. Log relative supply is the log of ratio of total hours workers by workers in the corresponding education group. Tertiary includes all with $12+$ years of education, Inomplete secondary includes all with 5-10 years of education. Wage measures are composition adjusted, supply measures are in efficiency unit. See appendix for how the data is processed. Standard errors in parentheses, ${ }^{* * *} \mathrm{p}<0.01,{ }^{* *} \mathrm{p}<0.05{ }^{*} \mathrm{p}<0.1$. 
Table 2: Regression Results for Tertiary/Incomplete Secondary Log Wage Differential by Experience Groups, 1995-2013, All Full Time Workers Aged 16-65

\begin{tabular}{|c|c|c|c|c|c|c|}
\hline & \multicolumn{6}{|c|}{ Potential Experience Groups } \\
\hline & $\begin{array}{c}\text { All Experience } \\
\text { Groups }\end{array}$ & $\begin{array}{c}\text { All Experience } \\
\text { Groups }\end{array}$ & 1-10 Years & 11-20 Years & 21-30 Years & $31+$ Years \\
\hline \multirow[t]{2}{*}{ Aggregate Supply } & $-0.083^{* * *}$ & $-0.041^{* * *}$ & $-0.074^{* * *}$ & $-0.084^{* * *}$ & $-0.085^{* * *}$ & $-0.062^{* * *}$ \\
\hline & $(0.004)$ & $(0.012)$ & $(0.011)$ & $(0.018)$ & $(0.008)$ & $(0.008)$ \\
\hline \multirow{2}{*}{$\begin{array}{l}\text { Group Supply- } \\
\text { Aggregate Supply }\end{array}$} & $-0.005^{* *}$ & $-0.005^{* * *}$ & 0.009 & -0.023 & -0.03 & 0.025 \\
\hline & $(0.002)$ & $(0.002)$ & $(0.018)$ & $(0.021)$ & $(0.026)$ & $(0.016)$ \\
\hline \multirow{2}{*}{$\begin{array}{l}\text { Unemployment } \\
\text { Rate }\end{array}$} & $-0.07^{* *}$ & $-0.052^{*}$ & -0.074 & -0.07 & -0.051 & -0.051 \\
\hline & $(0.03)$ & $(0.027)$ & $(0.056)$ & $(0.066)$ & $(0.061)$ & $(0.047)$ \\
\hline \multirow[t]{2}{*}{ Time } & $0.003^{* * *}$ & $0.004^{* * *}$ & 0.002 & $0.003^{* * *}$ & $0.002^{* * *}$ & $0.002^{* * *}$ \\
\hline & $(0.0002)$ & $(0.0004)$ & $(0.001)$ & $(0.001)$ & $(0.0005)$ & $(0.0004)$ \\
\hline \multirow[t]{2}{*}{ Time^$^{\wedge} 2$} & & $-0.0002^{* * *}$ & & & & \\
\hline & & $(0.00005)$ & & & & \\
\hline \multirow[t]{2}{*}{ Constant } & $0.017^{* * *}$ & $0.011^{* *}$ & 0.024 & 0.019 & 0.023 & 0.00597 \\
\hline & $(0.005)$ & $(0.005)$ & $(0.014)$ & $(0.012)$ & -0.0137 & -0.0084 \\
\hline Observations & 64 & 64 & 16 & 16 & 16 & 16 \\
\hline R-squared & 0.967 & 0.974 & 0.969 & 0.97 & 0.969 & 0.972 \\
\hline $\begin{array}{l}\text { Note: Regression ba } \\
\text { total hours workers } \\
\text { education, Inomple } \\
\text { supply measures ar } \\
\mathrm{p}<0.05 \text {, }^{*} \mathrm{p}<0.1 \text {. }\end{array}$ & $\begin{array}{l}\text { sed on samples } \\
\text { by workers in th } \\
\text { te secondary incl } \\
\text { e in efficiency un }\end{array}$ & $\begin{array}{l}\text { generated from } P \\
\text { e corresponding } \\
\text { udes all with 5-1 } \\
\text { it. See appendix }\end{array}$ & $\begin{array}{l}\text { D 1995-201 } \\
\text { ucation gro } \\
\text { ears of educ } \\
\text { data proces }\end{array}$ & $\begin{array}{l}\text { ata. Log relat } \\
\text { Tertiary inclu } \\
\text { n. Wage mea } \\
\text { s. Standard er }\end{array}$ & $\begin{array}{l}\text { supply is the } \\
s \text { all with } 12+ \\
\text { es are compos } \\
\text { s in parenthes }\end{array}$ & $\begin{array}{l}\text { f ratio of } \\
\text { s of } \\
\text { n adjusted, } \\
k * * \text { p }<0.01, * *\end{array}$ \\
\hline
\end{tabular}


Table 3: Regression Results for Tertiary/Incomplete Secondary Log Wage Differential by Experience Groups, 1995-2013, Male Full Time Workers Aged 16-65

\begin{tabular}{|c|c|c|c|c|c|c|}
\hline & \multicolumn{6}{|c|}{ Potential Experience Groups } \\
\hline & $\begin{array}{c}\text { All Experience } \\
\text { Groups }\end{array}$ & $\begin{array}{l}\text { All Experience } \\
\text { Groups }\end{array}$ & 1-10 Years & $11-20$ Years & 21-30 Years & $31+$ Years \\
\hline \multirow[t]{2}{*}{ Aggregate Supply } & $-0.091^{* * *}$ & $-0.041^{* * *}$ & $-0.084^{* * *}$ & $-0.084^{* * *}$ & $-0.091^{* * *}$ & $-0.062^{* * *}$ \\
\hline & $(0.005)$ & $(0.011)$ & $(0.012)$ & $(0.016)$ & $(0.01)$ & $(0.008)$ \\
\hline \multirow{2}{*}{$\begin{array}{l}\text { Group Supply- } \\
\text { Aggregate Supply }\end{array}$} & $-0.007^{* * *}$ & $-0.007^{* * *}$ & -0.001 & $-0.043^{* *}$ & -0.04 & $0.041^{* *}$ \\
\hline & $(0.002)$ & $(0.002)$ & $(0.017)$ & $(0.018)$ & $(0.04)$ & $(0.016)$ \\
\hline \multirow[t]{2}{*}{$\begin{array}{l}\text { Unemployment } \\
\text { Rate }\end{array}$} & $-0.068^{*}$ & -0.042 & -0.075 & -0.053 & -0.044 & -0.04 \\
\hline & $(0.039)$ & $(0.033)$ & $(0.081)$ & $(0.078)$ & $(0.081)$ & $(0.052)$ \\
\hline \multirow[t]{2}{*}{ Time } & $0.002^{* * *}$ & $0.004^{* * *}$ & $0.002^{*}$ & $0.003^{* * *}$ & $0.002^{* *}$ & $0.002^{* * *}$ \\
\hline & $(0.0002)$ & $(0.0004)$ & $(0.001)$ & $(0.0005)$ & $(0.001)$ & $(0.0003)$ \\
\hline \multirow[t]{2}{*}{ Time $^{\wedge} 2$} & & $-0.0002^{* * *}$ & & & & \\
\hline & & $(0.00005)$ & & & & \\
\hline \multirow[t]{2}{*}{ Constant } & -0.006 & -0.007 & -0.004 & -0.016 & -0.003 & $-0.017^{*}$ \\
\hline & $(0.007)$ & $(0.006)$ & $(0.016)$ & $(0.014)$ & $(0.018)$ & $(0.009)$ \\
\hline $\begin{array}{c}\text { Observations } \\
\text { R-squared }\end{array}$ & $\begin{array}{c}64 \\
0.949 \\
\end{array}$ & $\begin{array}{c}64 \\
0.964 \\
\end{array}$ & $\begin{array}{c}16 \\
0.952 \\
\end{array}$ & $\begin{array}{c}16 \\
0.967 \\
\end{array}$ & $\begin{array}{c}16 \\
0.954 \\
\end{array}$ & $\begin{array}{c}16 \\
0.972 \\
\end{array}$ \\
\hline $\begin{array}{l}\text { Note: Regression be } \\
\text { total hours workers } \\
\text { education, Inomple } \\
\text { supply measures ar } \\
p<0.05,{ }^{*} p<0.1 \text {. }\end{array}$ & $\begin{array}{l}\text { sed on samples } \\
\text { by workers in th } \\
\text { e secondary incl } \\
\text { e in efficiency un }\end{array}$ & $\begin{array}{l}\text { enerated from } P \\
\text { e corresponding } \\
\text { udes all with } 5-1 \\
\text { it. See appendix f }\end{array}$ & $\begin{array}{l}\text { U 1995-201 } \\
\text { ucation gro } \\
\text { ears of educ } \\
\text { data proces }\end{array}$ & $\begin{array}{l}\text { ata. Log relati } \\
\text { Tertiary inclu } \\
\text { n. Wage meas } \\
\text { g. Standard er }\end{array}$ & $\begin{array}{l}\text { supply is the } \\
\mathrm{s} \text { all with } 12+ \\
\text { es are compos } \\
\text { s in parenthes }\end{array}$ & $\begin{array}{l}\text { f ratio of } \\
\text { s of } \\
n \text { adjusted, } \\
k * * \text { p }<0.01,\end{array}$ \\
\hline
\end{tabular}


Table 4: Regression Results for Tertiary/Incomplete Secondary Log Wage Differential by Experience Groups, 1995-2013, Female Full Time Workers Aged 16-65

\begin{tabular}{|c|c|c|c|c|c|c|}
\hline & \multicolumn{6}{|c|}{ Potential Experience Groups } \\
\hline & $\begin{array}{c}\text { All Experience } \\
\text { Groups }\end{array}$ & $\begin{array}{c}\text { All Experience } \\
\text { Groups }\end{array}$ & 1-10 Years & 11-20 Years & $21-30$ Years & $31+$ Years \\
\hline \multirow[t]{2}{*}{ Aggregate Supply } & $-0.058 * * *$ & $-0.024 * * *$ & $-0.052^{* * *}$ & $-0.061^{* * *}$ & $-0.061^{* * *}$ & $-0.048^{* * *}$ \\
\hline & $(0.004)$ & $(0.008)$ & $(0.008)$ & $(0.013)$ & $(0.008)$ & $(0.008)$ \\
\hline \multirow{2}{*}{$\begin{array}{l}\text { Group Supply- } \\
\text { Aggregate Supply }\end{array}$} & -0.0002 & -0.0002 & 0.012 & -0.002 & -0.008 & 0.009 \\
\hline & $(0.002)$ & $(0.002)$ & $(0.011)$ & $(0.014)$ & $(0.016)$ & $(0.016)$ \\
\hline \multirow{2}{*}{$\begin{array}{l}\text { Unemployment } \\
\text { Rate }\end{array}$} & $-0.11^{* * *}$ & $-0.065^{* * *}$ & $-0.093^{*}$ & $-0.122^{*}$ & $-0.111^{*}$ & -0.084 \\
\hline & $(0.025)$ & $(0.024)$ & $(0.043)$ & $(0.056)$ & $(0.054)$ & $(0.052)$ \\
\hline \multirow[t]{2}{*}{ Time } & $0.002^{* * *}$ & $0.003^{* * *}$ & 0.001 & $0.002^{* *}$ & $0.002^{* * *}$ & $0.002^{* * *}$ \\
\hline & $(0.0002)$ & $(0.0002)$ & $(0.001)$ & $(0.001)$ & $(0.001)$ & $(0.0004)$ \\
\hline \multirow[t]{2}{*}{ Time`$^{\wedge} 2$} & & $-0.0001^{* * *}$ & & & & \\
\hline & & $(0.00003)$ & & & & \\
\hline \multirow[t]{2}{*}{ Constant } & $0.049 * * *$ & $0.04^{* * *}$ & $0.057^{* * *}$ & $0.068^{* * *}$ & $0.06^{* * *}$ & $0.036^{* * *}$ \\
\hline & $(0.005)$ & $(0.005)$ & $(0.011)$ & $(0.011)$ & $(0.013)$ & $(0.011)$ \\
\hline Observations & 64 & 64 & 16 & 16 & 16 & 16 \\
\hline R-squared & 0.988 & 0.991 & 0.972 & 0.965 & 0.964 & 0.958 \\
\hline $\begin{array}{l}\text { Note: Regression b } \\
\text { total hours workers } \\
\text { education, Inomple } \\
\text { supply measures ar } \\
\mathrm{p}<0.05 \text {, }^{*} \mathrm{p}<0.1 \text {. }\end{array}$ & $\begin{array}{l}\text { sed on samples } \\
\text { by workers in th } \\
\text { te secondary incl } \\
\text { e in efficiency un }\end{array}$ & $\begin{array}{l}\text { generated from } P \\
\text { e corresponding } \\
\text { udes all with 5-1 } \\
\text { it. See appendix }\end{array}$ & $\begin{array}{l}\text { AD 1995-201 } \\
\text { ducation gro } \\
\text { years of educ } \\
\text { r data proces }\end{array}$ & $\begin{array}{l}\text { ata. Log relati } \\
\text { Tertiary inclu } \\
\text { n. Wage meas } \\
\text { g. Standard er }\end{array}$ & $\begin{array}{l}\text { supply is the } \\
\text { s all with } 12+J \\
\text { es are compos } \\
s \text { in parenthes }\end{array}$ & $\begin{array}{l}\text { f ratio of } \\
\text { s of } \\
\text { n adjusted, } \\
k * * \text { p }<0.01, * *\end{array}$ \\
\hline
\end{tabular}




\section{Table 5: Datt-Ravallion Decomposition (Shapley Value) : Full Time Male Workers Aged 25-65 with Tertiary Education (12+ Years), 1995 VS 2013}

Case 1 :Average wage of male tertiary group in 1995 as the threshold $\mathrm{u} 1=1, \mathrm{u} 2=$ average in $1995 /$ average in $2013=1.228$

Growth Effect= $\quad .5 *[H(\mathrm{u} 2, \mathrm{~L} 2)-\mathrm{H}(\mathrm{u} 1, \mathrm{~L} 2)+\mathrm{H}(\mathrm{u} 2, \mathrm{~L} 1)-\mathrm{H}(\mathrm{u} 1, \mathrm{~L} 1)] \quad \mathbf{0 . 0 8 4 8}$

Redistribution effect= $.5 *[H(\mathrm{u} 1, \mathrm{~L} 2)-\mathrm{H}(\mathrm{u} 1, \mathrm{~L} 1)+\mathrm{H}(\mathrm{u} 2, \mathrm{~L} 2)-\mathrm{H}(\mathrm{u} 2, \mathrm{~L} 1)] \quad \mathbf{0 . 0 3 9 2}$

Case 2 :Average wage of male tertiary group in 2013 as the threshold u1=average in 2013/average in 1995=.815, u2=1

Growth Effect= $\quad .5 *[\mathrm{H}(\mathrm{u} 2, \mathrm{~L} 2)-\mathrm{H}(\mathrm{u} 1, \mathrm{~L} 2)+\mathrm{H}(\mathrm{u} 2, \mathrm{~L} 1)-\mathrm{H}(\mathrm{u} 1, \mathrm{~L} 1)] \quad \mathbf{0 . 0 9 4 9}$

Redistribution effect= $.5^{*}[\mathrm{H}(\mathrm{u} 1, \mathrm{~L} 2)-\mathrm{H}(\mathrm{u} 1, \mathrm{~L} 1)+\mathrm{H}(\mathrm{u} 2, \mathrm{~L} 2)-\mathrm{H}(\mathrm{u} 2, \mathrm{~L} 1)] \quad \mathbf{0 . 0 5 8 5}$

Note: The above is calculated based on PNAD 1995 and 2013 data, samples are full time (worked at least 140 hours in the survey month) male workers (employer, employee and self-employed are all included) with $12+$ years of education, aged between 25 and 65, wage measure is in 1995 price. 


\section{Table 6:}

\begin{tabular}{|c|c|c|c|c|c|c|c|c|c|c|c|}
\hline \multicolumn{6}{|c|}{$\begin{array}{l}\text { Average Hourly Wage by Birth Cohort in Each Survey Year: } \\
\text { Male with Tertiary Education (12+ Years) Aged 25-65 }\end{array}$} & \multicolumn{6}{|c|}{ Number of Observations in Each Birth Cohort-Survey Year Cell } \\
\hline \multirow[b]{2}{*}{ Cohort Group } & \multicolumn{5}{|c|}{ Survey Year } & \multirow[b]{2}{*}{ Cohort Group } & \multicolumn{5}{|c|}{ Survey Year } \\
\hline & 1995 & 1999 & 2003 & 2007 & 2011 & & 1995 & 1999 & 2003 & 2007 & 2011 \\
\hline 1985-1988 & & & & & 4.38 & 1985-1988 & & & & & 467 \\
\hline 1981-1984 & & & & 4.37 & 5.64 & 1981-1984 & & & & 482 & 1256 \\
\hline 1977-1980 & & & 4.24 & 5.47 & 6.62 & $1977-1980$ & & & 311 & 1090 & 1300 \\
\hline 1973-1976 & & 5.28 & 5.13 & 6.54 & 7.83 & 1973-1976 & & 237 & 727 & 977 & 1050 \\
\hline 1969-1972 & 5.73 & 6.09 & 6.82 & 7.22 & 9.02 & 1969-1972 & 200 & 579 & 727 & 923 & 923 \\
\hline $1965-1968$ & 7.44 & 7.57 & 7.29 & 8.16 & 7.18 & $1965-1968$ & 595 & 743 & 801 & 924 & 1191 \\
\hline 1961-1964 & 8.51 & 8.68 & 8.69 & 9.10 & 9.31 & 1961-1964 & 766 & 833 & 863 & 933 & 874 \\
\hline $1957-1960$ & 9.41 & 8.75 & 8.76 & 9.38 & 10.76 & $1957-1960$ & 825 & 817 & 838 & 843 & 650 \\
\hline $1953-1956$ & 10.96 & 10.03 & 9.18 & 10.33 & 11.53 & $1953-1956$ & 787 & 777 & 724 & 730 & 522 \\
\hline 1949-1952 & 11.72 & 10.08 & 10.13 & 10.71 & 12.26 & 1949-1952 & 665 & 596 & 586 & 517 & 379 \\
\hline 1945-1948 & 12.47 & 10.74 & 9.88 & 11.03 & 11.83 & $1945-1948$ & 500 & 452 & 352 & 332 & 180 \\
\hline 1941-1944 & 12.24 & 10.89 & 10.71 & 10.34 & & 1941-1944 & 312 & 225 & 204 & 127 & \\
\hline $1937-1940$ & 14.97 & 10.97 & 11.03 & & & $1937-1940$ & 192 & 145 & 111 & & \\
\hline
\end{tabular}

Note: Generated based on PNAD 1995-2013 data, full time (worked at least 140 hours in the survey month) male workers (employer, employee and self-employed are included) aged 25-65 with tertiary education (12+ years). Hourly wage measure of each year is in 1995 price. The 1st and 99th percentiles of each year's wage distribution are trimmed. 
Table 7: Effects of Cohort-Specific Tertiary Share on Relative Wage of Tertiary Group: Male Aged 25-65

\begin{tabular}{|c|c|c|c|}
\hline & All Samples & Younger: 25-35 & Older: 36-65 \\
\hline & $(1)$ & $(2)$ & $(3)$ \\
\hline \multirow[t]{2}{*}{ Cohort Tertiary Share } & $-0.310^{* * *}$ & 0.049 & $-0.381 * * *$ \\
\hline & $(0.101)$ & -0.173 & $(0.122)$ \\
\hline \multirow[t]{2}{*}{ Cohort Size } & 0.102 & -0.165 & 0.168 \\
\hline & $(0.096)$ & $(0.152)$ & $(0.116)$ \\
\hline \multirow[t]{2}{*}{ Young Age Dummy } & 0.025 & & \\
\hline & $(0.016)$ & & \\
\hline \multirow[t]{2}{*}{ Middle Age Dummy } & 0.017 & & \\
\hline & $(0.014)$ & & \\
\hline Year Dummy & Included & Included & Included \\
\hline \multirow[t]{2}{*}{ Constant } & $-0.062^{* * *}$ & $-0.068 * *$ & $-0.059 * *$ \\
\hline & $(0.02)$ & $(0.026)$ & $(0.025)$ \\
\hline Observations & 369 & 99 & 270 \\
\hline R-squared & 0.196 & 0.335 & 0.196 \\
\hline \multicolumn{4}{|c|}{$\begin{array}{l}\text { Note: Based on PNAD } 1995-2013 \text { data, wage is adjusted to } 1995 \text { price using CPI conversion factor. Samples include } \\
\text { full time male workers with tertiary education }(12+\text { years) aged between } 25 \text { and } 65 \text { with positive working experience, } \\
\text { worked at least } 140 \text { hours per month, not working without pay or domestic workers. Robust standard errors in } \\
\text { parentheses, }{ }^{* * *} p<0.01,{ }^{* *} \text { p }<0.05,{ }^{*} \text { p }<0.1\end{array}$} \\
\hline
\end{tabular}

